\title{
Novel Pannexin-1-Coupled Signaling Cascade Involved in the Control of Endothelial Cell Function and NO- Dependent Relaxation
}

\author{
Mauricio A. Lillo $\mathbb{D}^{1},{ }^{1}$ Pablo S. Gaete $\mathbb{D}^{1},{ }^{1}$ Mariela Puebla $\mathbb{D}^{2}{ }^{2}$ Pía C. Burboa $\mathbb{D}^{1},{ }^{1}$ Inés Poblete, ${ }^{1}$ \\ and Xavier F. Figueroa $\mathbb{D}^{1}$ \\ ${ }^{1}$ Departamento de Fisiología, Facultad de Ciencias Biológicas, Pontificia Universidad Católica de Chile, Santiago 8330025, Chile \\ ${ }^{2}$ Centro de Fisiología Celular e Integrativa, Facultad de Medicina-Clínica Alemana, Universidad del Desarrollo, Santiago, Chile \\ Correspondence should be addressed to Xavier F. Figueroa; xfigueroa@bio.puc.cl
}

Received 29 May 2020; Revised 3 January 2021; Accepted 13 January 2021; Published 20 February 2021

Academic Editor: Paola Venditti

Copyright (c) 2021 Mauricio A. Lillo et al. This is an open access article distributed under the Creative Commons Attribution License, which permits unrestricted use, distribution, and reproduction in any medium, provided the original work is properly cited.

\begin{abstract}
Deletion of pannexin-1 (Panx-1) leads not only to a reduction in endothelium-derived hyperpolarization but also to an increase in NO-mediated vasodilation. Therefore, we evaluated the participation of Panx-1-formed channels in the control of membrane potential and $\left[\mathrm{Ca}^{2+}\right]_{\mathrm{i}}$ of endothelial cells. Changes in NO-mediated vasodilation, membrane potential, superoxide anion $\left(\mathrm{O}_{2}{ }^{--}\right)$ formation, and endothelial cell $\left[\mathrm{Ca}^{2+}\right]_{\mathrm{i}}$ were analyzed in rat isolated mesenteric arterial beds and primary cultures of mesenteric endothelial cells. Inhibition of Panx-1 channels with probenecid $(1 \mathrm{mM})$ or the Panx-1 blocking peptide ${ }^{10} \mathrm{Panx}(60 \mu \mathrm{M})$ evoked an increase in the $\mathrm{ACh}(100 \mathrm{nM})$-induced vasodilation of $\mathrm{KCl}$-contracted mesenteries and in the phosphorylation level of endothelial NO synthase (eNOS) at serine $1177\left(\mathrm{P}-\mathrm{eNOS}^{\mathrm{S} 1177}\right)$ and Akt at serine $473\left(\mathrm{P}-\mathrm{Akt}^{\mathrm{S} 473}\right)$. In addition, probenecid or ${ }^{10}$ Panx application activated a rapid, tetrodotoxin (TTX, $300 \mathrm{nM}$ )-sensitive, membrane potential depolarization and $\left[\mathrm{Ca}^{2+}\right]_{\mathrm{i}}$ increase in endothelial cells. Interestingly, the endothelial cell depolarization was converted into a transient spike after removing $\mathrm{Ca}^{2+}$ ions from the buffer solution and in the presence of $100 \mu \mathrm{M}$ mibefradil or $10 \mu \mathrm{M} \mathrm{Ni}^{2+}$. As expected, $\mathrm{Ni}^{2+}$ also abolished the increment in $\left[\mathrm{Ca}^{2+}\right]_{\mathrm{i}}$. Expression of $\mathrm{Na}_{\mathrm{v}} 1.2, \mathrm{Na}_{\mathrm{v}} 1.6$, and $\mathrm{Ca}_{\mathrm{v}} 3.2$ isoforms of voltage-dependent $\mathrm{Na}^{+}$and $\mathrm{Ca}^{2+}$ channels was confirmed by immunocytochemistry. Furthermore, the Panx-1 channel blockade was associated with an increase in $\mathrm{O}_{2}{ }^{-}$ production. Treatment with $10 \mu \mathrm{M}$ TEMPOL or $100 \mu \mathrm{M}$ apocynin prevented the increase in $\mathrm{O}_{2}^{--}$formation, ACh-induced vasodilation, $\mathrm{P}-\mathrm{eNOS}^{\mathrm{S} 1177}$, and $\mathrm{P}-\mathrm{Akt}^{\mathrm{S}}{ }^{73}$ observed in response to Panx-1 inhibition. These findings indicate that the Panx-1 channel blockade triggers a novel complex signaling pathway initiated by the sequential activation of TTX-sensitive $\mathrm{Na}_{\mathrm{v}}$ channels and $\mathrm{Ca}_{\mathrm{v}} 3.2$ channels, leading to an increase in NO-mediated vasodilation through a NADPH oxidase-dependent PeNOS $^{\mathrm{S1177}}$, which suggests that Panx-1 may be involved in the endothelium-dependent control of arterial blood pressure.
\end{abstract}

\section{Introduction}

Control of blood flow distribution relies on coordinated changes in the diameter of resistance arteries through a complex interplay between the vasoconstrictor and vasodilator signals that determines the degree of smooth muscle constriction (i.e., vasomotor tone). Endothelial cells play a critical role in this process by the activation of several signaling pathways that mediate the response initiated by different stimuli, which are, consequently, known as endothelium- dependent vasodilators $[1,2]$. Nitric oxide $(\mathrm{NO})$ has been recognized as the major vasodilator signal generated by endothelial cells; however, in small resistance arteries (i.e., feed arteries and arterioles), an additional vasodilator pathway associated with the NO-independent hyperpolarization of smooth muscle cells has also been described [2]. As this vasodilator pathway relies on the gap junction-mediated transmission to smooth muscle cells of a hyperpolarizing current initiated in the endothelium by the opening of $\mathrm{Ca}^{2+}$-activated $\mathrm{K}^{+}$channels $\left(\mathrm{K}_{\mathrm{Ca}}\right)$ of small $\left(\mathrm{SK}_{\mathrm{Ca}}\right)$ and 
intermediate $\left(\mathrm{IK}_{\mathrm{Ca}}\right)$ conductance [2-4], this vasodilator component was termed as endothelium-derived hyperpolarization (EDH) [5]. In addition, to mediate the EDH signaling, gap junction communication has also been shown to provide a preferential signaling pathway for $\mathrm{NO}$ and contribute to the coordination of vasomotor tone in the microcirculation [6]. Although gap junctions play a central role in the coordination of vascular function, a functional association in endothelial cells between voltage-dependent $\mathrm{Na}^{+}$channels $\left(\mathrm{Na}_{\mathrm{v}}\right)$ and T-type, voltage-dependent $\mathrm{Ca}^{2+}$ channels $\left(\mathrm{Ca}_{\mathrm{v}} 3\right)$ of the subtype $\mathrm{Ca}_{\mathrm{v}} 3.2$ has also been proposed to participate in this process by supporting the conduction of vasodilator signals $[2,7,8]$.

Gap junctions are intercellular channels formed by the serial docking of two hemichannels, each one provided by each neighboring cell, and, in turn, hemichannels are made up by the association of six protein subunits known as connexins. Interestingly, individual hemichannels might be functional, providing a pathway to connect the intra- and extracellular compartments [9-11]. Connexin-based channels may allow the release (hemichannels) or intercellular transfer (gap junction channels) of current, ions, and small signaling molecules $(<1.4 \mathrm{~nm}$ diameter $)$ such as ATP and $\mathrm{IP}_{3}$ [9-12]. In addition to connexins, channels formed by pannexins have emerged as an important signaling pathway for the control of vasomotor tone in resistance arteries [13]. Pannexins are a protein family structurally related to connexins; however, apparently, these proteins do not constitute functional gap junction channels in physiological conditions and only form membrane channels with similar characteristics to hemichannels, which have been proposed to function as a preferential pathway for ATP release [11, 14, 15].

Of the three pannexin isoforms described (Panx-1, Panx2 , and Panx-3), only Panx-1 has consistently been found in the vessel wall [16]. In resistance arteries, this pannexin isoform is expressed in endothelial and smooth muscle cells and the sympathetic nerve-triggered vasoconstriction initiated by $\alpha 1$-adrenoceptors has been reported to be mediated, in part, by ATP release from smooth muscle cells through Panx-1 channels $[13,16]$. In contrast, in conduit arteries, Panx-1 is only expressed in the endothelium [16] and the activation of a Panx-1 channel-initiated purinergic signaling was found to contribute to the EDH-dependent vasodilation elicited by the endothelium-dependent vasodilator, acetylcholine (ACh) [17]. However, although the EDH-mediated vasodilator pathway was reduced in Panx-1 knockout mice, the NO-dependent vasodilator component was enhanced in these animals, suggesting that Panx-1 may be involved in the tonic regulation of NO production by the endothelial isoform of the enzyme endothelial NO synthase (eNOS) [17].

In the present study, we examined the effect of acute Panx-1 channel inhibition on the NO-dependent vasodilation induced by ACh in mesenteric resistance arteries. To this end, we evaluated the variations in vasomotor responses in relation to the changes in membrane potential and intracellular $\mathrm{Ca}^{2+}$ concentration $\left(\left[\mathrm{Ca}^{2+}\right]_{\mathrm{i}}\right)$ observed in endothelial cells during the application of Panx-1 channel blockers. Our results show that the blockade of Panx-1 channels triggered a fast, transient, membrane depolarization-initiated increase in $\left[\mathrm{Ca}^{2+}\right]_{\mathrm{i}}$, which leads to the activation of a complex signaling cascade that evokes eNOS phosphorylation at serine 1177 $\left(\mathrm{P}-\mathrm{eNOS}^{\mathrm{S} 1177}\right)$ and the subsequent increment in the NOmediated vasodilator component.

\section{Materials and Methods}

Male Sprague-Dawley rats (200-230 g) were bred and maintained in the Research Animal Facility of the Pontificia Universidad Católica de Chile. All experimental protocols were conducted according to the Helsinki Declaration and the Guiding Principles of Care and Use of Laboratory Animals endorsed by the American Physiological Society. In addition, the study was approved by the Institutional Bioethics Committee.

2.1. Perfusion of the Isolated Mesenteric Arterial Bed. Rats were anesthetized with xylazine and ketamine (10 and $90 \mathrm{mg} / \mathrm{kg}$, i.p., respectively), and the mesenteric arterial bed was isolated as described by Lillo et al. [18]. Briefly, the superior mesenteric artery was cannulated and the mesentery was perfused at $2 \mathrm{~mL} / \mathrm{min}$ with a warmed $\left(37^{\circ} \mathrm{C}\right)$ Tyrode buffer solution (in mM: $118 \mathrm{NaCl}, 5.4 \mathrm{KCl}, 2.5 \mathrm{CaCl}_{2}, 1.2 \mathrm{KH}_{2} \mathrm{PO}_{4}$, $1.2 \mathrm{MgSO}_{4}, 23.8 \mathrm{NaHCO}_{3}$, and 11.1 glucose) that was bubbled with $95 \% \mathrm{O}_{2}-5 \% \mathrm{CO}_{2}$ to yield $\mathrm{pH} 7.35-7.45$. Immediately thereafter, the aorta was cut to ensure a fast killing by exsanguination and mesenteries were severed from the intestinal wall. Isolated mesenteric arterial beds were placed in a perfusion chamber, and the experiments were started after an equilibration period of $20 \mathrm{~min}$. Changes in perfusion pressure were recorded by means of a pressure transducer (P23Db Statham) connected at the entrance of the superior mesenteric artery and the WinDaq software (DataQ Instruments Inc., USA). All drugs were applied dissolved in the perfusion solution.

2.2. Vasomotor Responses. In the isolated mesenteric preparation, the intraluminal pressure of resistance arteries is low and does not reach the threshold to activate a myogenic response. Therefore, vessels were constricted with $70 \mathrm{mM}$ $\mathrm{KCl}$, since the ACh-elicited vasodilation depends exclusively on $\mathrm{NO}$ in $\mathrm{KCl}$-constricted mesenteries $[6,19]$. High- $\mathrm{KCl}$ solutions were prepared by equimolar substitution of $\mathrm{Na}^{+}$ ions for $\mathrm{K}^{+}$ions. The response to $\mathrm{ACh}$ was evaluated 15 min after blocking Panx-1 channels with $1 \mathrm{mM}$ probenecid, and the results were expressed as a percentage of reduction in the perfusion pressure (\% relaxation) or as a percentage of change in the perfusion pressure along the time (\% baseline).

2.3. Primary Cultures of Mesenteric Endothelial Cells. Microvascular endothelial cells were isolated as described by Ashley et al. [20]. Briefly, after removing the blood from the vessels by perfusing a sterile Tyrode buffer solution containing a mixture of antibiotics and antimycotics (Anti-Anti solution, Gibco, Invitrogen, NY, USA), mesenteries were incubated in a physiological saline solution containing $0.2 \%$ collagenase type I and $0.1 \% \mathrm{BSA}$ at $37^{\circ} \mathrm{C}$. After $1 \mathrm{~h}$, the collagenase/BSA solution was removed by two successive applications of $\mathrm{M}$ 199 media and centrifugation. Pelleted cells were 
resuspended in M-199 media containing $20 \mu \mathrm{g} / \mathrm{mL}$ endothelial cell growth supplement from bovine pituitary (ECGS) and $20 \%$ fetal bovine serum (FBS) and seeded onto sterile glass coverslips. Nonadherent cells were removed $4 \mathrm{~h}$ later, and the remaining adherent endothelial cells were kept at $37^{\circ} \mathrm{C}$ in a $5 \% \mathrm{CO}_{2}-95 \%$ air atmosphere at nearly $100 \%$ relative humidity. To carry out the experiments, the culture media of endothelial cells of 70 to $80 \%$ of confluence ( $\sim 2$ days of culture) were replaced by a MOPS-buffered Tyrode saline solution ( $\mathrm{pH} 7.4)$.

2.4. Measurements of Intracellular $\mathrm{Ca}^{2+}$ Concentration. Changes in $\left[\mathrm{Ca}^{2+}\right]_{\mathrm{i}}$ were detected using the fluorescent $\mathrm{Ca}^{2+}$ indicator, Fluo 4 (Life Technologies, OR, USA), as described previously [18]. Fluo 4 was uploaded by incubating the primary cultures of endothelial cells with $10 \mu \mathrm{M}$ Fluo 4acetoxymethyl ester (Fluo 4-AM) for $1 \mathrm{~h}$ at room temperature $\left(\sim 25^{\circ} \mathrm{C}\right)$, and time-lapse measurements of $\left[\mathrm{Ca}^{2+}\right]_{\mathrm{i}}$ were started after $20 \mathrm{~min}$ of equilibration using an Olympus BX50 WI microscope and an intensified CCD camera (Retiga Fast 1394, QImaging) controlled by the IPLab software (Scanalytics, Inc.). Variations in fluorescence intensity were expressed as $F / F_{0}$, where $F$ is the fluorescence observed during the recording period and $F_{0}$ is the baseline fluorescence value. Fluo 4-AM was prepared in DMSO and diluted to the working concentration in MOPS-buffered Tyrode solution.

2.5. Membrane Potential Recordings. Changes in membrane potential were recorded in primary cultures of endothelial cells and in smooth muscle cells of intact, isolated mesenteric resistance arteries (120-180 $\mu \mathrm{m}$ inner diameter) using glass pulled microelectrodes filled with $3 \mathrm{M} \mathrm{KCl}$ (pipette resistance: 30-60 M $\Omega$ ) connected to an electrometer DUO 773 (World Precision Instruments, Inc., FL, USA), as described by Lillo et al. [18]. In the case of smooth muscle recordings, resistance arteries were pinned down on a Sylgard ${ }^{\circledR}$ (Dow Corning Corporation, MI, USA) surface at the bottom of a chamber containing MOPS-buffered Tyrode solution ( $\mathrm{pH} 7.4$ ) and, to recognize the cell type impaled, the microelectrode filling solution also included $10 \mu \mathrm{M}$ dextran-FITC (MW: $3000 \mathrm{Da}$ ) in addition to $3 \mathrm{M} \mathrm{KCl}$. The preparation was grounded with an $\mathrm{Ag}-\mathrm{AgCl}$ reference electrode placed in the buffer solution, and, with the assistance of a microscope (Nikon Eclipse), the recording microelectrode was guided using an electronic micromanipulator (Burleigh TS5000-I50, NY) to impale an endothelial cell or the isolated artery. Successful cell impalement was recognized by a rapid negative deflection of potential, stable membrane potential in basal conditions, and positive deflection on exit. Changes in membrane potential were recorded at $1000 \mathrm{~Hz}$ unless otherwise indicated, using the data acquisition software LabScribe (iWorx Systems, Inc., NH, USA).

2.6. Superoxide Anion Measurements. The superoxide anion $\left(\mathrm{O}_{2}{ }^{-}\right)$probe dihydroethidine (DHE) was used to detect $\mathrm{O}_{2}{ }^{--}$ formation in intact resistance arteries and in primary cultures of mesenteric endothelial cells [21]. To measure $\mathrm{O}_{2}{ }^{-}$ in resistance arteries, isolated mesenteric arterial beds were perfused for 15 min with a Tyrode buffer solution containing $10 \mu \mathrm{M}$ DHE alone or in combination with Panx-1 channel blockers, probenecid $(1 \mathrm{mM})$ or ${ }^{10} \mathrm{Panx}(60 \mu \mathrm{M})$. The effect of the vehicle of the blockers was also evaluated as a control. DHE and blockers were washed out for $10 \mathrm{~min}$, and a small resistance artery $(120-180 \mu \mathrm{m}$ inner diameter, $\sim 1.0 \mathrm{~cm}$ length) was isolated and pinned down on a Sylgard ${ }^{\circledR}$ surface at the bottom of a $35 \mathrm{~mm}$ dish containing MOPS-buffered Tyrode solution ( $\mathrm{pH}$ 7.4). A similar protocol was used in cultured endothelial cells, but, in this case, the time course of the DHE-generated signal was recorded. DHE diffuses into the cell and is oxidized by reactive oxygen species (ROS) to form ethidium, which produces nuclear fluorescence after intercalating with DNA. The fluorescent signal was examined by epifluorescence (exciter: $530-550 \mathrm{~nm}$, band-pass filter; emission: $590 \mathrm{~nm}$, long-pass filter) using an intensified CCD camera (Retiga Fast 1394, QImaging) and the IPLab software (Scanalytics, Inc.). The analysis of the fluorescence intensity was performed using the software ImageJ. As the DHE fluorescent signal is not specific for $\mathrm{O}_{2}{ }^{--}$, these measurements were complemented with the direct $\mathrm{O}_{2}{ }^{\cdot-}$ detection using the analysis by emitted light $\left(\mathrm{ABEL}^{\circledR}\right)$ assay, which is based on the intense luminescence emitted upon the reaction of $\mathrm{O}_{2}{ }^{-}$ radicals with the prosthetic group of pholasin, the photoprotein responsible for luminescence in the bivalve Pholas dactylus $[22,23]$ (see Supplementary Materials (available here)).

2.7. Western Blot. Mesenteries were homogenized, and proteins were separated by $12 \%$ SDS-PAGE and transferred onto a PVDF membrane (Pierce, Rockford, IL, USA), as described previously [18]. The Signal Enhancer HIKARI (Nacalai Tesque, Inc., Japan) was used to incubate the primary (BD Transduction Labs, Lexington, KY, USA) and secondary antibodies (Pierce, Rockford, IL, USA), the molecular mass was estimated with prestained markers (Bio-Rad, Hercules, CA, USA), and the protein bands were detected with the SuperSignal ${ }^{\circledR}$ West Femto (Pierce, Rockford, IL, USA). Blots were developed for eNOS phosphorylation at serine 1177 (P$\mathrm{eNOS}^{\mathrm{S1177}}$ ) and then stripped three times successively to reprobe the membranes for total eNOS, Akt phosphorylation at serine $473\left(\mathrm{P}-\mathrm{Akt}^{\mathrm{S} 473}\right)$, and total Akt. Protein bands were analyzed using the ImageJ software, and changes in eNOS and Akt phosphorylation were expressed as the ratio of phosphorylated protein over total protein. In an additional experimental series, a group of mesenteries was perfused for 30 min with a $\mathrm{Ca}^{2+}$-free Tyrode buffer solution equilibrated with $95 \% \mathrm{O}_{2}-5 \% \mathrm{CO}_{2}(\mathrm{pH} 7.35-7.45)$ at $37^{\circ} \mathrm{C}$ as described above, but containing $0.5 \mathrm{mg} / \mathrm{mL}$ collagenase type II (Worthington, Lakewood, NJ, USA) to remove the endothelium. Then, mesenteric arteries were perfused with a control Tyrode buffer solution for an additional $5 \mathrm{~min}$ and the tissue was homogenized and prepared for Western blot analysis. In addition, expression of $\mathrm{Na}_{\mathrm{v}} 1.2, \mathrm{Na}_{\mathrm{v}} 1.6$, and $\mathrm{Ca}_{\mathrm{v}} 3.2$ channels in the plasma membrane was analyzed by biotinylation of cell surface proteins (see Supplementary Materials (available here)).

2.8. Immunocytochemistry Analysis. Mesenteric arterial beds were first perfused for $10 \mathrm{~min}$ and then incubated overnight 


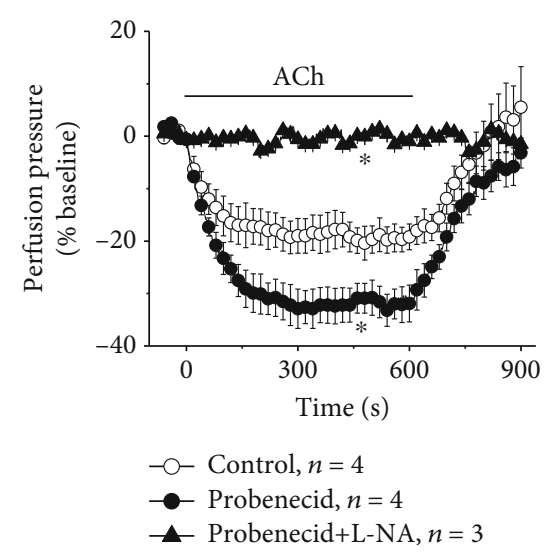

(a)
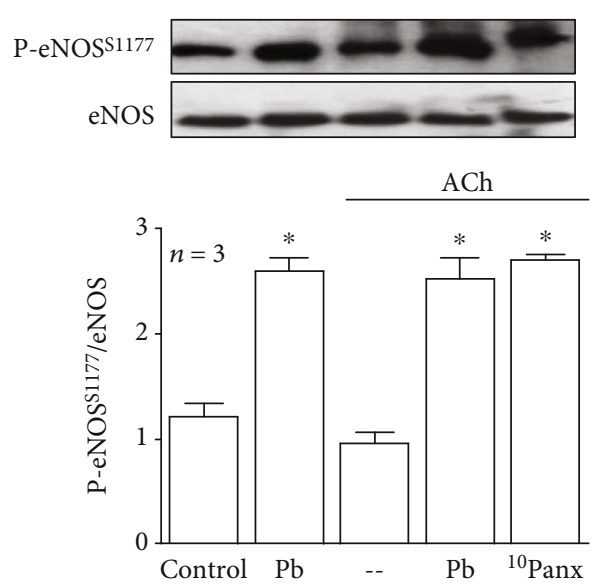

(b)
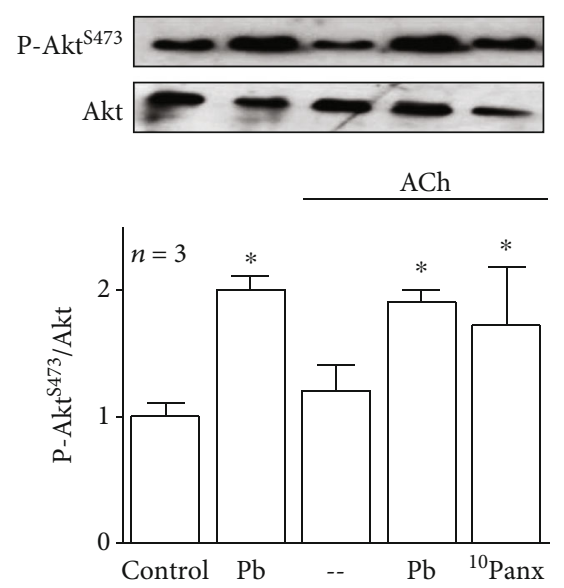

(c)

Figure 1: Blockade of Panx-1 channels enhances the NO-mediated vasodilation activated by ACh. (a) Time course of the vasodilation induced by $100 \mathrm{nM} \mathrm{ACh}$ in $\mathrm{KCl}$-contracted arterial mesenteric beds in control conditions and in the presence (15 min) of $1 \mathrm{mM}$ probenecid alone or in addition to the treatment for $45 \mathrm{~min}$ with $100 \mu \mathrm{M} \mathrm{N}$-nitro-L-arginine (L-NA), a blocker of NO production. Probenecid was applied during the last $15 \mathrm{~min}$ of the treatment with L-NA. The horizontal bar indicates the period of stimulation. (b, c) Representative Western blots and densitometric analysis of eNOS (b) and Akt (c) expression as well as the phosphorylation of eNOS at serine $1177\left(\mathrm{P}-\mathrm{eNOS}^{\mathrm{S} 1177},(\mathrm{~b})\right)$ and Akt at serine $473\left(\mathrm{P}-\mathrm{Akt}^{\mathrm{S}}{ }^{73},(\mathrm{c})\right)$ observed in basal conditions (control) and after the treatment with $1 \mathrm{mM}$ probenecid $(\mathrm{Pb})$ or $60 \mu \mathrm{M}{ }^{10} \mathrm{Panx}$. In the densitometric analysis, the changes in eNOS and Akt phosphorylation are expressed as the ratio of phosphorylated protein over total protein. Values are means \pm SEM. ${ }^{*} P<0.05$ vs. the control by one-way ANOVA plus the Newman-Keuls post hoc test.

with Bouin's solution to fix and postfix the tissue, respectively. Subsequently, mesenteric arteries were prepared for immunohistochemistry or immunofluorescence analysis, as described previously [7, 18]. Tissues were dehydrated, embedded in paraffin, sectioned $(10 \mu \mathrm{m})$, placed on chargecoated slides, and deparaffinized using standard procedures to analyze the expression of $\mathrm{Na}_{\mathrm{v}} 1.2, \mathrm{Na}_{\mathrm{v}} 1.6$, and $\mathrm{Ca}_{\mathrm{v}} 3.2$ channels by immunohistochemistry or Panx-1 and caveolin-1 (Cav-1) by immunofluorescence. The expression of $\mathrm{Na}_{\mathrm{v}} 1.2$, $\mathrm{Na}_{\mathrm{v}} 1.6$, and $\mathrm{Ca}_{\mathrm{v}} 3.2$ channels was also assessed by immunofluorescence in cultured endothelial cells fixed with $4 \%$ paraformaldehyde. For immunohistochemistry, tissue sections were blocked with $0.5 \%$ BSA in TBS ( $\mathrm{pH} 7.4$ ) for $1 \mathrm{~h}$ at room temperature and prepared as indicated by the Mouse/Rabbit ImmunoDetector System (Bio SB, Santa Barbara, CA, USA) protocol. After blocking the endogenous peroxidase activity, sections were incubated overnight at $4^{\circ} \mathrm{C}$ with anti- $\mathrm{Na}_{\mathrm{v}} 1.2$, anti- $\mathrm{Na}_{\mathrm{v}} 1.6$, or anti-Ca 3.2 rabbit primary antibodies (Alomone Laboratories, Israel) and the signal was developed using the biotin link secondary antibody (10 min), HPR label, and DAB chromogen of the Mouse/Rabbit ImmunoDetector System. For immunofluorescence, sections and endothelial cell monolayers were blocked with $0.5 \%$ BSA in PBS and incubated with the anti-Panx-1 rabbit primary antibody (Sigma-Aldrich, St. Louis, MO, USA) or anti-Cav-1 mouse primary antibody (BD Transduction Labs, Lexington, KY, USA) in the case of tissue sections or anti- $\mathrm{Na}_{\mathrm{v}} 1.2$, anti$\mathrm{Na}_{\mathrm{v}} 1.6$, or anti-Ca 3.2 primary antibodies in the case of cultured cells and then with the appropriate Alexa Fluor 568labeled goat anti-rabbit or anti-mouse secondary antibody (Molecular Probes, OR, USA) using the Signal Enhancer HIKARI (Nacalai Tesque, Inc., Japan) as indicated by the manufacturer. The fluorescent signal was examined using an Olympus BX41 WI microscope and a CCD camera (Jenoptik ProgRes C5).

2.9. Analysis of Panx-1 Subcellular Distribution. The potential subcellular localization of Panx-1 channels in caveolae was evaluated by assessing the spatial association between Panx-1 and Cav-1 using the Proximity Ligation Assay (PLA, Duolink II, Olink Bioscience, Sweden) as described previously [18]. Tissue sections $(10 \mu \mathrm{m})$ were blocked with $0.5 \%$ BSA and incubated with rabbit polyclonal anti-Panx-1 (Sigma-Aldrich) and mouse monoclonal anti-Cav-1 (BD Transduction Labs) primary antibodies, which were detected using oligonucleotide-conjugated secondary antibodies as described in the manufacturer's protocols. The oligonucleotides can meet each other if the proteins are closer than $20 \mathrm{~nm}$ and thus can be used as a template for DNA ligasemediated joining of additional oligonucleotides to form a circular DNA molecule, which was amplified using hybridizing fluorophore-labeled oligonucleotides. Primary antibodies were omitted as a negative control. Images were visualized with an Olympus LSM FLUOVIEW 1000 confocal microscope.

2.10. Chemicals. All chemicals of analytical grade were obtained from Merck (Darmstadt, Germany). MOPS, EGTA, ECGS, BSA, DHE, ACh, probenecid, dextran-FITC (MW: $3000 \mathrm{Da})$, mibefradil, $\mathrm{Ni}^{2+}, 18 \beta$-glycyrrhetinic acid $(\beta-\mathrm{GA})$, methyl- $\beta$-cyclodextrin $(\mathrm{M} \beta \mathrm{CD})$, and $\mathrm{N}^{\mathrm{G}}$-nitro-L-arginine (L-NA) were purchased from Sigma-Aldrich (St. Louis, MO, USA). Apocynin and TEMPOL were obtained from Calbiochem (La Jolla, CA, USA), tetrodotoxin (TTX) from Affix Scientific, and collagenase type I from Worthington (Lakewood, NJ, USA). The Panx-1 channel blocking peptide 
${ }^{10}$ Panx was synthesized by GenScript (Israel). $\beta$-GA and apocynin were dissolved in DMSO and probenecid in $0.5 \mathrm{M}$ $\mathrm{NaOH}$. These inhibitors were then diluted in a buffer solution to reach the final working concentration (final amount of $\mathrm{DMSO}<0.1 \%$ and $1.4 \mathrm{mM} \mathrm{NaOH})$. DMSO did not have an effect per se (data not shown). The $\mathrm{pH}$ of the final solution of probenecid was checked before the experiments, and the effect of the vehicle was also evaluated.

2.11. Statistical Analysis. Values are represented as mean \pm standard error. Comparisons between groups were made using paired or unpaired Student's $t$-test, one-way ANOVA plus the Newman-Keuls post hoc test, or two-way ANOVA as appropriate. $P<0.05$ was considered significant.

\section{Results}

The endothelium-dependent vasodilation was analyzed in mesenteric resistance arteries precontracted with $70 \mathrm{mM}$ KCl. Perfusion pressure of mesenteric arterial beds was 3.7 $\pm 0.8 \mathrm{mmHg}$ in resting conditions and increased during the stimulation with $\mathrm{KCl}$ to $20.9 \pm 2.3 \mathrm{mmHg}$ in $2-3 \mathrm{~min}(n=6$ ). Application of $100 \mathrm{nM}$ ACh for $10 \mathrm{~min}$ evoked the relaxation of mesenteric resistance arteries, which was reflected in a rapid reduction in perfusion pressure that reached a maximum after $\sim 2$ min of stimulation and gradually returned to the $\mathrm{KCl}$ preconstriction level after the end of $\mathrm{ACh}$ application (Figure 1(a)).

3.1. Control of NO-Mediated Vasodilation by Panx-1 Channels. Mesenteric arteries were treated with probenecid to evaluate the participation of Panx-1-formed channels in response to $\mathrm{ACh}$. Although probenecid application did not affect the basal perfusion pressure of mesenteric arterial beds (see Supplementary Fig. S1a and S1b), treatment with this blocker attenuated the vasoconstriction evoked by $\mathrm{KCl}$ (see Supplementary Fig. S2) and enhanced the ACh-induced vasodilation (Figure $1(\mathrm{a})$ ). In $\mathrm{KCl}$-contracted arteries, the endothelium-dependent vasodilation relies exclusively on NO production $[6,19]$ (see Supplementary Fig. S3) and, consistent with this notion, inhibition of NO production with $100 \mu \mathrm{M}$ L-NA abolished the vasodilation activated by ACh in the presence of probenecid (Figure 1(a)). Then, we evaluated the effect of the Panx-1 channel blockade on PeNOS $^{\mathrm{S} 1177}$, which is a regulatory mechanism that enhances $\mathrm{Ca}^{2+}$-mediated NO production. A basal P-eNOS ${ }^{\mathrm{S1177}}$ was detected in control conditions, and the larger vasodilation observed in the presence of probenecid was associated with an increment in the P-eNOS ${ }^{\mathrm{S} 1177}$ level (Figure 1(b)) and also in Akt phosphorylation at serine $473\left(\mathrm{P}-\mathrm{Akt}^{\mathrm{S}}{ }^{2}\right.$, Figure $1(\mathrm{c})$ ), suggesting that the eNOS phosphorylation triggered by the Panx-1 channel blockade was mediated by the activation of the PI3K/Akt signaling pathway, as previously observed in response to different stimuli such as shear stress or bradykinin [24-26]. In line with previous reports [19], stimulation with ACh did not alter the level of P-eNOS ${ }^{\text {S1177 }}$ and P$\mathrm{Akt}^{\mathrm{S} 473}$ observed in basal conditions or after inhibiting Panx-1 channels with probenecid or the Panx-1 blocking peptide ${ }^{10}$ Panx (Figures 1(b) and 1(c)). Altogether, these results suggest that Panx-1 channels present a basal activity that may be involved in the regulation of endothelial cell function.

\subsection{Voltage-Dependent $\mathrm{Ca}^{2+}$ Signaling Triggered by the Panx-} 1 Channel Blockade. Control of membrane potential plays an important role in the regulation of endothelial cell signaling and in the $\mathrm{Ca}^{2+}$-dependent eNOS activation; thus, we evaluated the effect of the Panx-1 channel blockade on endothelial cell membrane potential. Surprisingly, in primary cultures of mesenteric endothelial cells, application of Panx-1 channel blockers, probenecid or ${ }^{10}$ Panx, evoked a fast tetrodotoxin(TTX-) sensitive membrane depolarization that reached a maximum in $\sim 40 \mathrm{~ms}$ and returned to the control level after a plateau phase of $\sim 7 \mathrm{~s}$ (Figures $2(\mathrm{a})-2(\mathrm{c})$ ). This response was also observed in smooth muscle cells of intact mesenteric resistance arteries (Figures 2(d)-2(f)). However, endothelial and smooth muscle cells are connected through gap junctions (i.e., myoendothelial gap junctions) and the inhibition of these intercellular channels with $18 \beta$-glycyrrhetinic acid ( $50 \mu \mathrm{M}, \beta$-GA) completely prevented the smooth muscle cell depolarization elicited by probenecid (Figures 2(e) and 2(f)). In contrast, $\beta$-GA did not affect the response recorded in endothelial cells (Figure 2(c)), indicating that the depolarizing signal was triggered in the endothelium by the activation of TTX-sensitive, voltage-dependent $\mathrm{Na}^{+}$channels $\left(\mathrm{Na}_{\mathrm{v}}\right)$ and thus transmitted to smooth muscle cells via myoendothelial gap junctions.

The activation of $\mathrm{Na}_{\mathrm{v}}$ channels is anticipated to be transient, which suggests the possible contribution of a second component in the endothelium-dependent depolarization triggered by the Panx-1 channel blockade, such as a $\mathrm{Ca}^{2+}$ influx. Consistent with this hypothesis, the plateau phase of the probenecid-activated depolarization was not observed after removing $\mathrm{Ca}^{2+}$ ions from the buffer solution (i.e., $\mathrm{Ca}^{2+}$-free solution) or in the presence of $100 \mu \mathrm{M}$ mibefradil or $10 \mu \mathrm{M} \mathrm{Ni}^{2+}$ (Figures 3(a) and 3(b)), suggesting that the initial $\mathrm{Na}_{\mathrm{v}}$-mediated depolarization was coupled to the subsequent activation of $\mathrm{Ca}_{\mathrm{v}} 3$ channels, most likely, the subtype $\mathrm{Ca}_{\mathrm{v}}$ 3.2. In addition, the plateau of the depolarization was paralleled by a prominent increase in $\left[\mathrm{Ca}^{2+}\right]_{i}$ (Figures $3(\mathrm{c})$ and $3(d))$ that showed the same temporal characteristics of the change in membrane potential (Figure 2(a)) and, as expected, was abolished by $\mathrm{Ni}^{2+}$, but also by TTX (Figure 3(d)), supporting the notion that the activation of the $\mathrm{Ca}^{2+}$ signal was triggered by TTX-sensitive $\mathrm{Na}_{\mathrm{v}}$ channels.

These findings suggest that TTX-sensitive $\mathrm{Na}_{\mathrm{v}}$ channels and $\mathrm{Ca}_{\mathrm{v}} 3.2$ channels are present in endothelial cells and the expression of the isoforms $\mathrm{Na}_{\mathrm{v}} 1.2$ and $\mathrm{Na}_{\mathrm{v}} 1.6$ of TTXsensitive $\mathrm{Na}_{\mathrm{v}}$ channels as well as the isoform $\mathrm{Ca}_{\mathrm{v}} 3.2$ of $\mathrm{Ca}_{\mathrm{v}} 3$ channels has been detected in the endothelium [7,27], which we confirmed by immunocytochemistry analysis in mesenteric resistance arteries. Both $\mathrm{Na}_{\mathrm{v}} 1.2$ and $\mathrm{Na}_{\mathrm{v}} 1.6$ channels were found to be expressed in endothelial cells as well as in smooth muscle cells, but, in contrast, the staining for $\mathrm{Ca}_{\mathrm{v}} 3.2$ channels was confined exclusively to the endothelium (Figure 4(a)). In addition, the expression of $\mathrm{Na}_{\mathrm{v}} 1.2, \mathrm{Na}_{\mathrm{v}} 1.6$, and $\mathrm{Ca}_{\mathrm{v}} 3.2$ channels in the endothelium was corroborated in primary cultures of mesenteric endothelial cells by 


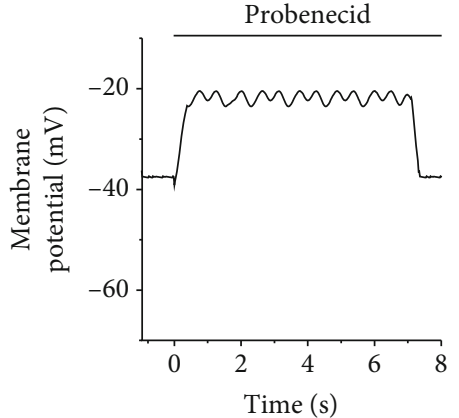

(a)

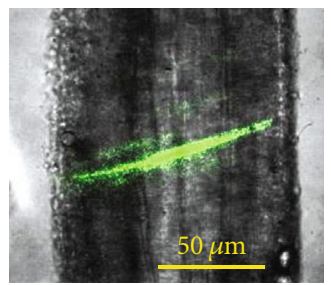

(d)

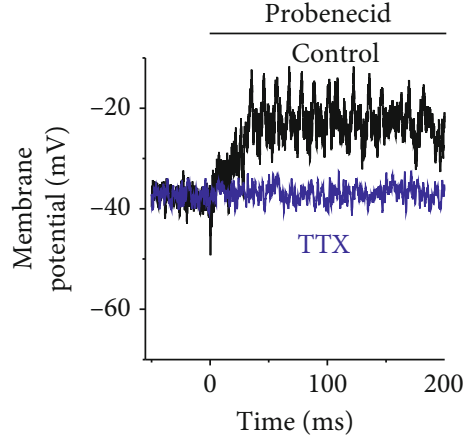

(b)

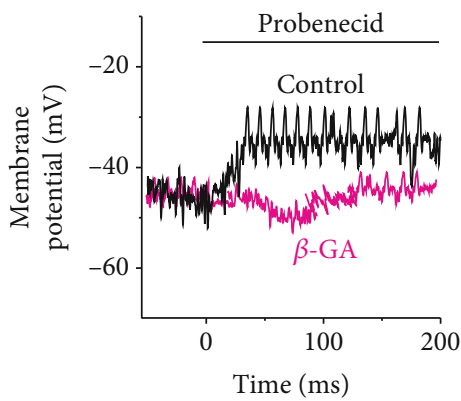

(e)

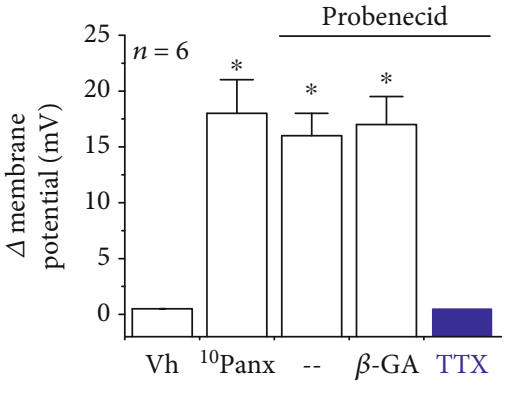

(c)

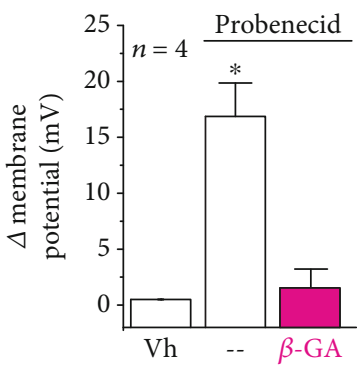

(f)

Figure 2: Blockade of Panx-1 triggers a rapid tetrodotoxin- (TTX-) sensitive depolarization of endothelial cell membrane potential. (a) Time course of the changes in membrane potential evoked by the Panx-1 channel blockade with $1 \mathrm{mM}$ probenecid in primary cultures of endothelial cells. Membrane potential was recorded at $100 \mathrm{~Hz}$. (b) Representative recordings of the membrane depolarization observed in primary cultures of endothelial cells in response to probenecid in control conditions and in the presence of $300 \mathrm{nM}$ TTX. (c) Analysis of the maximum depolarization evoked by the application of $60 \mu \mathrm{M}{ }^{10} \mathrm{Panx}$ or $1 \mathrm{mM}$ probenecid and its vehicle (Vh). Resting membrane potential was not affected by the vehicle of probenecid or ${ }^{10} \mathrm{Panx}$. The effect of $50 \mu \mathrm{M} 18 \beta$-glycyrrhetinic acid $(\beta$-GA) and TTX is also shown. (d) Representative image of a smooth muscle cell microinjected with dextran-FITC (3000 Da) during the recording of the changes in membrane potential from the smooth muscle layer of an isolated mesenteric resistance artery. (e) Representative recordings of the changes in membrane potential observed in intact arteries in response to the Panx-1 channel blockade with probenecid in control conditions and in the presence of $\beta$-GA. (f) Analysis of the maximum smooth muscle depolarization activated by probenecid in control conditions and in the presence of $\beta$-GA. The effect of the vehicle $(\mathrm{Vh})$ of probenecid is also shown. Values are means $\pm \mathrm{SEM}$. ${ }^{*} P<0.05$ vs. the vehicle by one-way ANOVA plus the Newman-Keuls post hoc test.

immunofluorescence (Figure 4(b)) and in intact mesenteric resistance arteries with $\left(\mathrm{E}^{+}\right)$or without endothelium $\left(\mathrm{E}^{-}\right)$by Western blot (Figure 4(c)). Consistent with the immunocytochemistry analysis, removal of the endothelium by perfusing resistance vessels with collagenase resulted in a striking reduction in the Western blot signal for $\mathrm{Na}_{\mathrm{v}} 1.2$ and $\mathrm{Na}_{\mathrm{v}} 1.6$ channels, but the presence of $\mathrm{Ca}_{\mathrm{v}} 3.2$ channels was practically undetectable in endothelium-denuded vessels (Figure 4(c)), confirming the preferential endothelial cell expression of these channels in the wall of resistance arteries. In this experimental series, the reduction in the eNOS signal after endothelial cell removal was also evaluated as a control (Figure 4(c)). $\mathrm{Na}_{\mathrm{v}} 1.2, \mathrm{Na}_{\mathrm{v}} 1.6$, and $\mathrm{Ca}_{\mathrm{v}} 3.2$ channels must be found at the plasma membrane to be functional, which we further analyzed by biotinylation of surface proteins of the endothelial cell luminal membrane in intact mesenteric resistance vessels (see Supplementary Fig. S4). As expected, all three channels, $\mathrm{Na}_{\mathrm{v}} 1.2, \mathrm{Na}_{\mathrm{v}} 1.6$, and $\mathrm{Ca}_{\mathrm{v}} 3.2$, were found in the biotin-labeled protein fraction, in addition to the whole vessel sample (see Supplementary Fig. S4), indicating that these channels are expressed at the endothelial cell plasma membrane. It should be noted that perfusion of biotin did not reach intracellular proteins of endothelial cells or plasma membrane proteins of smooth muscle cells because this treatment did not target eNOS or L-type voltage-dependent $\mathrm{Ca}^{2+}$ channels, $\mathrm{Ca}_{\mathrm{v}} 1.2$, respectively. In contrast, a relevant membrane protein of endothelial cells, such as the $\mathrm{Na}^{+}$$\mathrm{Ca}^{2+}$ exchanger, was also found in the biotin-labeled protein fraction (see Supplementary Fig. S4).

\subsection{Panx-1 Subcellular Distribution in Resistance Arteries.} Signaling microdomains, such as caveolae, play a central role in the control of vascular function and in the regulation of NO production; therefore, we analyzed the cellular distribution of Panx-1 and Cav-1, a structural protein of caveolae, in mesenteric resistance arteries by immunofluorescence analysis and Proximity Ligation Assay (PLA). The fluorescent signal for Panx-1 and Cav-1 was detected in endothelial cells as well as in smooth muscle cells (Figure 5(a)), and the analysis of PLA revealed that both proteins are found in close spatial proximity mainly in endothelial cells (Figure 5(b)). The association of Panx-1 with Cav-1 was confirmed in primary cultures of mesenteric endothelial cells, and, interestingly, the blockade of Panx-1 channels with ${ }^{10}$ Panx evoked 


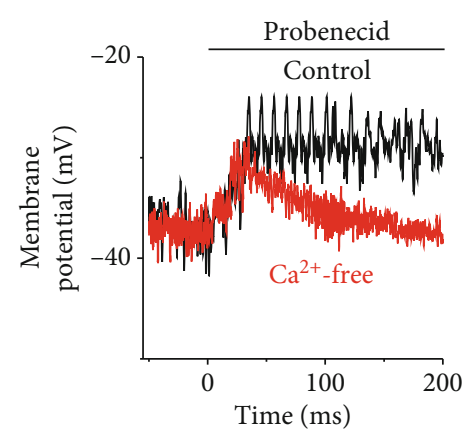

(a)
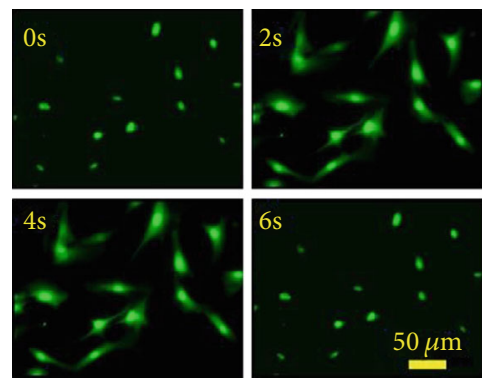

(c)

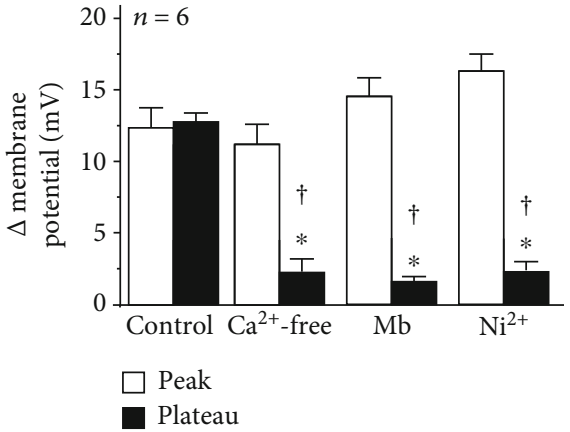

(b)
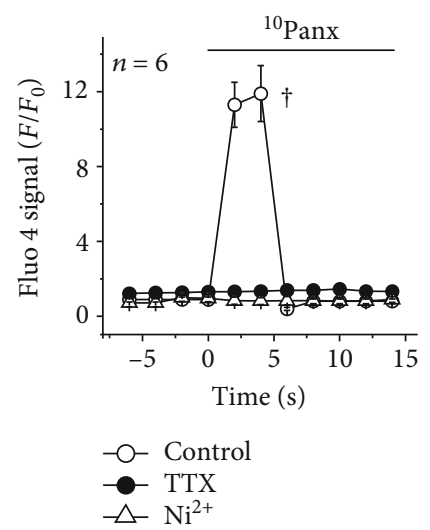

(d)

Figure 3: T-type voltage-dependent $\mathrm{Ca}^{2+}$ channels (T-type $\mathrm{Ca}_{\mathrm{v}}$ ) are involved in the endothelial cell depolarization evoked by the Panx-1 channel blockade. (a) Representative recordings of the changes in endothelial cell membrane potential evoked by $1 \mathrm{mM}$ probenecid in control conditions or after removing $\mathrm{Ca}^{2+}$ ions from the buffer solution $\left(\mathrm{Ca}^{2+}\right.$-free solution plus $2 \mathrm{mM}$ EGTA). Note that the absence of extracellular $\mathrm{Ca}^{2+}$ ions unmasked two components: an initial peak and a $\mathrm{Ca}^{2+}$-dependent plateau phase. Treatment with the $\mathrm{Ca}^{2+}$-free solution was initiated $5 \mathrm{~min}$ before probenecid application. (b) Analysis of the peak and plateau phase of the depolarization evoked by probenecid in control conditions and during the treatment with a $\mathrm{Ca}^{2+}$-free solution, $100 \mu \mathrm{M}$ mibefradil $(\mathrm{Mb})$, or $10 \mu \mathrm{M} \mathrm{Ni}{ }^{2+}$. (c, d) Representative images (c) and quantitative analysis (d) of the changes in $\left[\mathrm{Ca}^{2+}\right]_{\mathrm{i}}$ observed in response to the Panx-1 channel blockade with $60 \mu \mathrm{M}{ }^{10} \mathrm{Panx}$ in primary cultures of endothelial cells. Note that tetrodotoxin (TTX, $300 \mathrm{nM}$ ) and $\mathrm{Ni}^{2+}$ abolished the increase in $\left[\mathrm{Ca}^{2+}\right]_{\mathrm{i}}$ activated by ${ }^{10} \mathrm{Panx}$. Values are means \pm SEM. ${ }^{*} P<0.05$ vs. the peak by paired Student's $t$-test. ${ }^{\dagger} P<0.05$ vs. the control by oneway ANOVA plus the Newman-Keuls post hoc test.

an increase in the level of spatial interaction between these two proteins (Figure 5(c)), which suggests that the organization of the signaling mechanism initiated by the Panx-1 channel blockade is orchestrated in caveolae. Consistent with this hypothesis, disruption of cholesterol-rich microdomains by treating the cultures of endothelial cells with $5 \mathrm{mM}$ methyl- $\beta$-cyclodextrin $(\mathrm{M} \beta \mathrm{CD})$ for $30 \mathrm{~min}$ fully prevented the endothelial cell depolarization and the increase in $\left[\mathrm{Ca}^{2+}\right]_{\mathrm{i}}$ observed in response to ${ }^{10} \mathrm{Panx}$ application (Figures 6(a)-6(c)).

\subsection{Panx-1 Channel Blockade Leads to NADPH Oxidase-} Derived Superoxide Formation. As depolarization of membrane potential as well as an increase in $\left[\mathrm{Ca}^{2+}\right]_{\mathrm{i}}$ may trigger the activation of NADPH oxidase in endothelial cells [2830], we used DHE to assess $\mathrm{O}_{2}{ }^{--}$production in intact mesenteric resistance arteries and primary cultures of mesenteric endothelial cells. The blockade of Panx-1 channels with probenecid or ${ }^{10} \mathrm{Panx}$ in resistance vessels resulted in a strong increment in the DHE-generated fluorescent signal
(Figures $7(\mathrm{a})$ and $7(\mathrm{~b})$ ) that was fully prevented by $10 \mu \mathrm{M}$ TEMPOL (Figure $7(\mathrm{c})$ ), $\mathrm{a} \mathrm{O}_{2}{ }^{--}$dismutase mimetic, confirming that the increase in the $\mathrm{DHE}$ signal reflected $\mathrm{O}_{2}{ }^{--}$production. Additionally, the rise in $\mathrm{O}_{2}{ }^{--}$levels observed in response to the Panx-1 channel blockade was also corroborated using the photoprotein pholasin (see Supplementary Fig. S5). As expected, stimulation with $\mathrm{ACh}$ did not change the $\mathrm{O}_{2}{ }^{-}$ levels observed in control conditions or after the treatment with probenecid (Figures $7(\mathrm{a})$ and $7(\mathrm{~b})$ ). The activation of $\mathrm{O}_{2}{ }^{--}$formation was rapid, since, in cultured endothelial cells, the increase in the DHE signal started immediately after probenecid application (Figure $7(d)$ ). In agreement with the participation of NADPH oxidase in the response, the increase in $\mathrm{O}_{2}{ }^{--}$was abolished by $100 \mu \mathrm{M}$ apocynin, an inhibitor of NADPH oxidase, in both resistance arteries (Figure $7(\mathrm{c})$ ) and endothelial cell cultures (Figures $7(\mathrm{~d})$ and $7(\mathrm{e})$ ). In addition to TEMPOL and apocynin, $\mathrm{O}_{2}{ }^{--}$formation was also inhibited by $10 \mu \mathrm{M} \mathrm{Ni}{ }^{2+}$ (Figure $7(\mathrm{f})$ ), supporting the involvement of $\mathrm{Ca}_{\mathrm{v}} 3.2$ channels in the NADPH oxidase activation. 

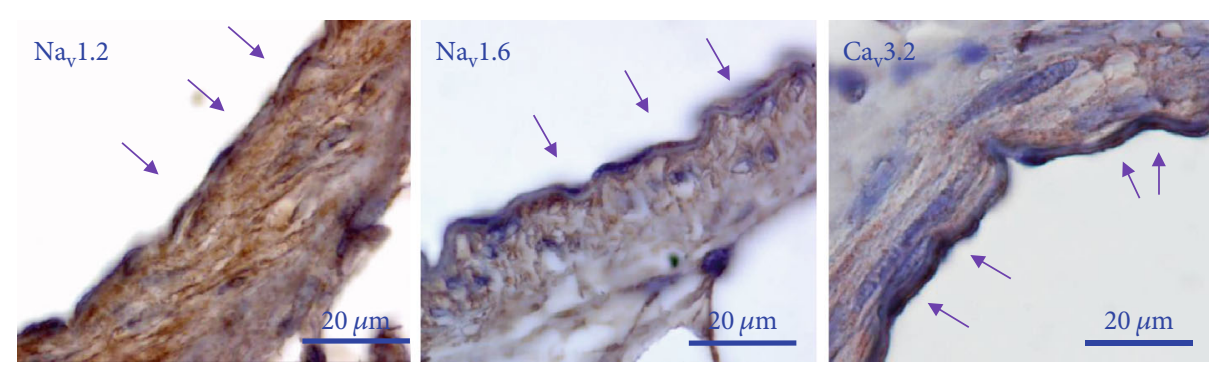

(a)
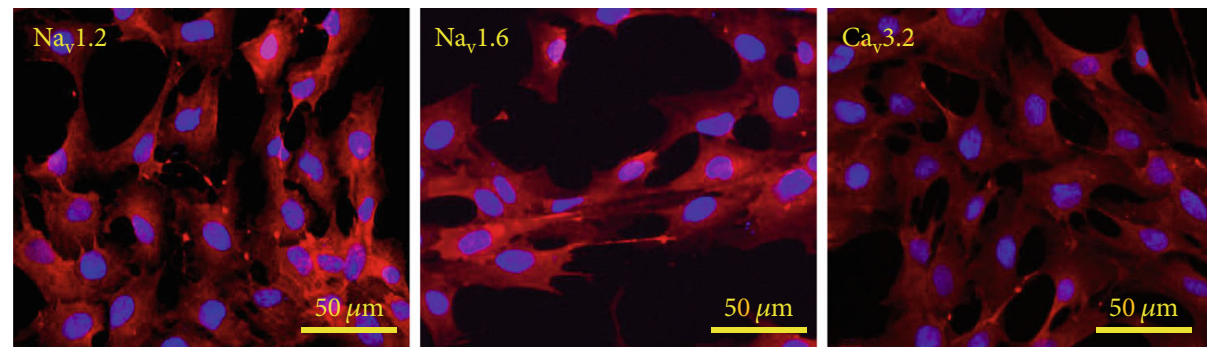

(b)
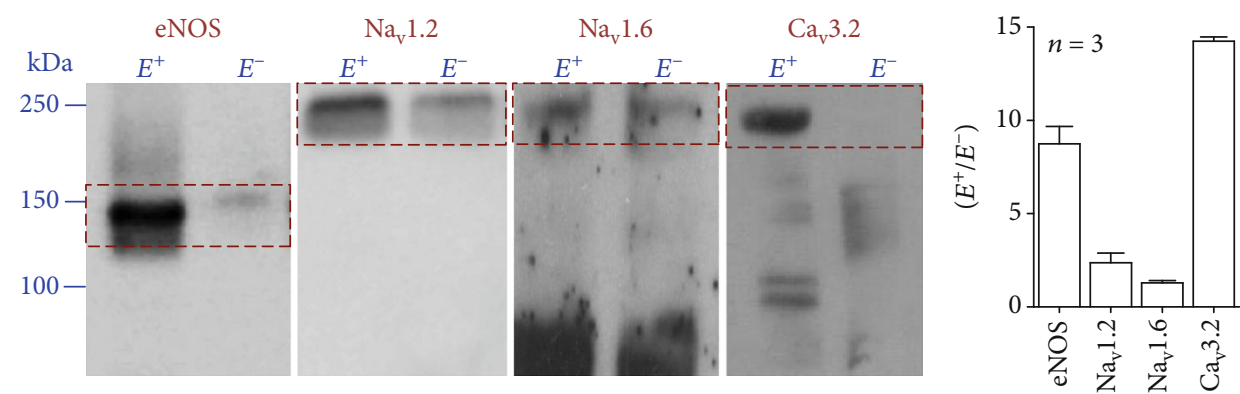

(c)

FIgURE 4: Expression of voltage-dependent $\mathrm{Na}^{+}\left(\mathrm{Na}_{\mathrm{v}}\right)$ and $\mathrm{Ca}^{2+}\left(\mathrm{Ca}_{\mathrm{v}}\right)$ channels in endothelial cells of mesenteric resistance arteries. (a) Immunohistochemistry analysis of the cellular distribution of $\mathrm{Na}_{\mathrm{v}}$ and $\mathrm{Ca}_{\mathrm{v}}$ channel-specific isoforms $\mathrm{Na}_{\mathrm{v}} 1.2, \mathrm{Na}_{\mathrm{v}} 1.6$, and $\mathrm{Ca}_{\mathrm{v}} 3.2$ in the wall of mesenteric resistance arteries. Note that $\mathrm{Na}_{\mathrm{v}} 1.2$ and $\mathrm{Na}_{\mathrm{v}} 1.6$ channels are present in both endothelial cells and smooth muscle cells, but $\mathrm{Ca}_{\mathrm{v}} 3.2$ channels are expressed exclusively in the endothelium. Arrows highlight the staining observed in endothelial cells. (b) Immunofluorescence detection of the expression of $\mathrm{Na}_{\mathrm{v}} 1.2, \mathrm{Na}_{\mathrm{v}} 1.6$, and $\mathrm{Ca}_{\mathrm{v}} 3.2$ channels in primary cultures of mesenteric endothelial cells. (c) Representative Western blots and densitometric analysis of the expression of eNOS and $\mathrm{Na}_{\mathrm{v}} 1.2, \mathrm{Na}_{\mathrm{v}} 1.6$, and $\mathrm{Ca}_{\mathrm{v}} 3.2$ channels in intact mesenteric arteries before $\left(\mathrm{E}^{+}\right)$and after $\left(\mathrm{E}^{-}\right)$removing the endothelium by the treatment with collagenase.

\subsection{NADPH Oxidase Mediates the eNOS Activation Triggered} by the Panx-1 Channel Blockade. The NADPH oxidasederived $\mathrm{O}_{2}{ }^{--}$production initiated by the Panx-1 channel blockade may lead to the activation of Akt-mediated signaling [31]; therefore, we evaluated if the NADPH oxidase $/ \mathrm{O}_{2}^{-}$- $/$Akt pathway was involved in the $\mathrm{P}$-eNOS ${ }^{\mathrm{S1177}}$ associated increase in NO-dependent vasodilation. Consistent with this hypothesis, the increase in the level of $\mathrm{P}$ $\mathrm{Akt}^{\mathrm{S}}{ }^{73}$ and $\mathrm{P}-\mathrm{eNOS}{ }^{\mathrm{S} 1177}$ observed after probenecid application was not evident in the presence of $10 \mu \mathrm{M}$ TEMPOL (Figures $8(\mathrm{a})$ and $8(\mathrm{~b})$ ). In line with these results, treatment with TEMPOL or apocynin $(100 \mu \mathrm{M})$ completely inhibited both the increment in the ACh-induced vasodilation (Figures 8(c) and 8(d)) and the reduction in the $\mathrm{KCl}$ evoked vasoconstriction (see Supplementary Fig. S6a and S6b) attained after blocking Panx-1 channels with probenecid, which strongly support the involvement of the NADPH oxidase $/ \mathrm{O}_{2}{ }^{--}$pathway in the Panx-1-mediated regulation of NO-dependent vasodilation.

\section{Discussion}

The relevance of Panx-1 channels in the control of endothelium-mediated vasomotor signaling is not clear. In spite of this cavity in the Panx physiology, deletion of Panx-1 was reported to attenuate the $\mathrm{EDH}$ pathway, and, interestingly, a compensatory increase in the NO-mediated vasodilation was also observed in the absence of this protein, suggesting that EDH or directly Panx-1 channels may be involved in a negative feedback mechanism that restrains NO production [17]. However, in contrast to this notion, our results show that the acute blockade of Panx-1 channels triggers a complex signaling pathway that leads to $\mathrm{P}-\mathrm{eNOS}^{\mathrm{S11}}$ in response to a NADPH oxidase-mediated increase in $\mathrm{O}_{2}{ }^{-}$ formation. Interestingly, this mechanism is triggered by a TTX-sensitive depolarization that is coupled to a $\mathrm{Ca}^{2+}$ influx through $\mathrm{Ca}_{\mathrm{v}} 3$ channels, apparently, the subtype $\mathrm{Ca}_{\mathrm{v}} 3.2$.

Blood flow distribution is controlled by the fine regulation of the diameter of small resistance arteries. In these 

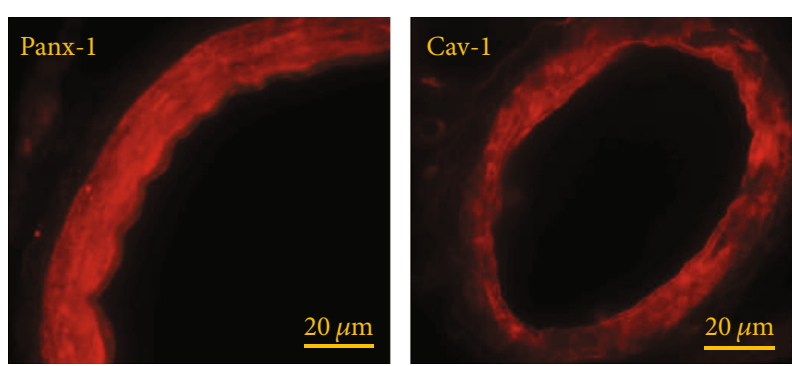

(a)

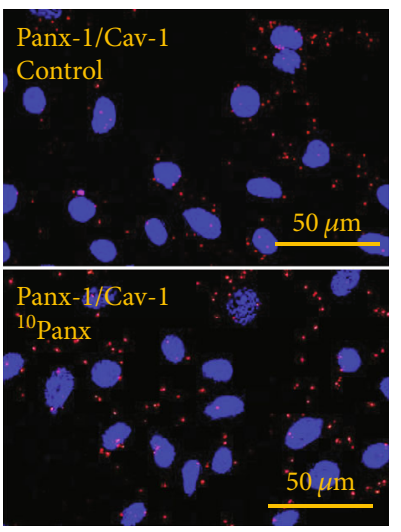

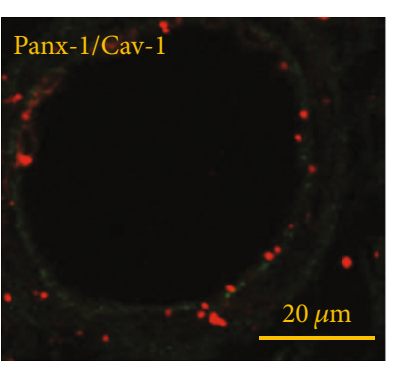

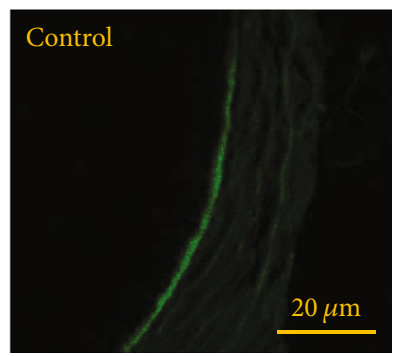

(b)

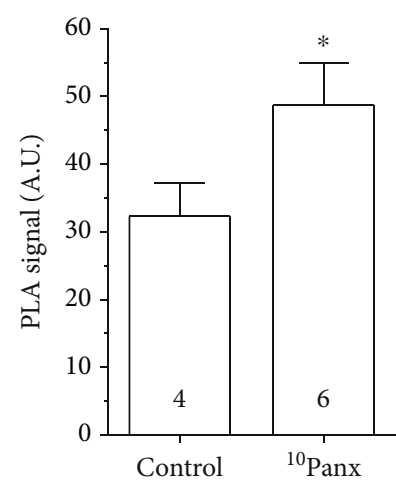

(c)

FIgure 5: Panx-1 is associated with caveolin-1 (Cav-1) in endothelial cells. (a) Immunofluorescence analysis of the cellular distribution of Panx-1 (left) and Cav-1 (right) in mesenteric resistance arteries. (b) Analysis performed by Proximity Ligation Assay (PLA) of the spatial association of Panx-1 with Cav-1 (left) and the negative control (right) in which primary antibodies were omitted. Note that although Panx-1 and Cav-1 are expressed in endothelial cells and smooth muscle cells, the association between these two proteins is mainly observed in the endothelium. The green fluorescent signal corresponds to the internal elastic lamina. (c) Representative images (left) and fluorescence intensity analysis (right) of the PLA-detected association between Panx-1 and Cav-1 in primary cultures of mesenteric endothelial cells in control conditions and $5 \mathrm{~min}$ after the application of the Panx-1 blocking peptide ${ }^{10}$ Panx. Changes in the PLA signal are expressed in arbitrary units (A.U.). Numbers inside the bars indicate the $n$ value. Values are means \pm SEM. ${ }^{*} P<0.05$ vs. the control by unpaired Student's $t$-test.

arteries, Panx-1 is expressed not only in endothelial cells but also in smooth muscle cells [16] (Figure 5). Although the physiological relevance of Panx-1-mediated signaling in the control of vascular function is just beginning to be understood, channels formed by Panx-1 have been shown to be involved in the vasoconstriction initiated by the stimulation of $\alpha 1$-adrenoceptors in smooth muscle cells of resistance arteries [13] and in the EDH-mediated vasodilator component activated by ACh in conduit arteries [17]. Furthermore, Panx-1 has also been associated with the regulation of NO signaling, but the mechanism involved in this process has not been determined [17]. Therefore, to focus on the NOdependent vasodilator component elicited by ACh, without interfering with the Panx-1-mediated vasoconstrictor signaling initiated by $\alpha 1$-adrenoceptors in smooth muscle cells, we used $\mathrm{KCl}$-contracted resistance arteries to disable the EDH signaling and evoke a receptor-independent contraction. The ACh-induced vasodilation depends exclusively on NO in these conditions $[19,32]$ (Supplementary Fig. S3), and, therefore, the increase in response to ACh observed after the treatment with probenecid (Figure 1) confirmed that the blockade of Panx-1 channels enhances the endothelium-mediated NO signaling, as further demonstrated by the inhibition of NO production with L-NA
(Figure 1). Consistent with increased NO production, probenecid also attenuated the $\mathrm{KCl}$-evoked vasoconstriction (see Supplementary Fig. S2). Interestingly, the increase in the response was associated with an increment in $\mathrm{P}$ $\operatorname{eNOS}^{\mathrm{S1177}}$ (Figure 1), which is consistent with the upregulation of the relaxation, since eNOS is a $\mathrm{Ca}^{2+}$-dependent enzyme and $\mathrm{P}$-eNOS ${ }^{\mathrm{S} 1177}$ is a well-characterized regulatory mechanism that enhances $\mathrm{Ca}^{2+}$-activated $\mathrm{NO}$ production $[33,34]$. Activation of the PI3K/Akt signaling pathway leads to P-eNOS ${ }^{S 1177}[24,25,35]$, and, in line with the participation of this pathway in the phosphorylation of eNOS, the Panx-1 channel blockade was also coupled to an increase in P-Akt ${ }^{\mathrm{S} 733}$ (Figure 1).

NO production and eNOS activity have been reported to be modulated by changes in endothelial cell membrane potential, and Panx-1 may work as a $\mathrm{Cl}^{-}$-selective channel in basal conditions [36], which may contribute to depolarize the endothelial cell membrane potential [37]. Then, we hypothesized that disruption of Panx-1 channel function may lead to an increase in NO production by triggering the hyperpolarization of membrane potential. Unexpectedly, the application of probenecid or ${ }^{10} \mathrm{Panx}$ evoked a rapid membrane potential depolarization in primary cultures of mesenteric endothelial cells as well as in smooth muscle cells of 


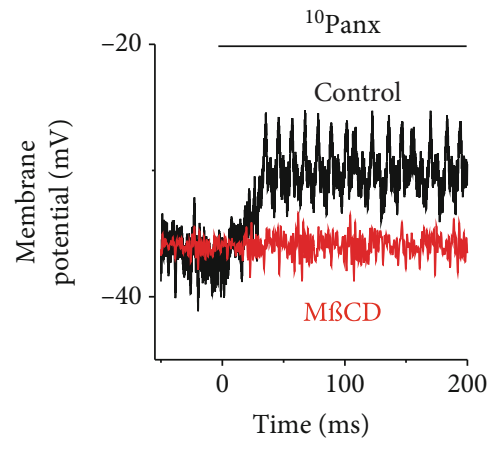

(a)

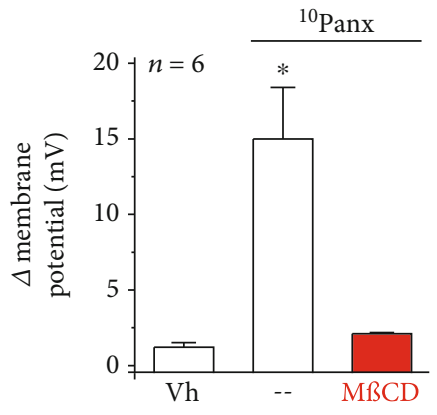

(b)

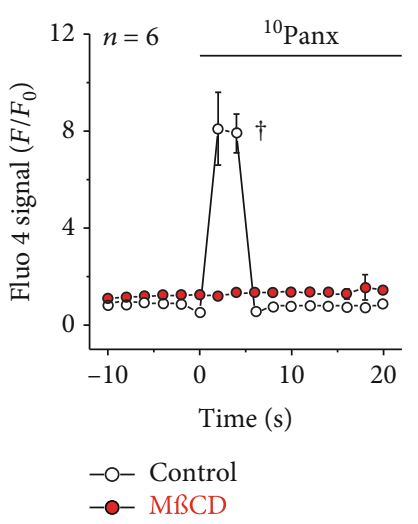

(c)

FIgURE 6: The depolarization and $\mathrm{Ca}^{2+}$ signaling activated in endothelial cells by the Panx-1 channel blockade depend on the integrity of cholesterol-rich microdomains. (a) Representative recordings of the changes in endothelial cell membrane potential evoked by $60 \mu \mathrm{M}$ ${ }^{10} \mathrm{Panx}$ in control conditions and after disrupting the cholesterol-rich signaling microdomains by the treatment with $5 \mathrm{mM}$ methyl- $\beta$ cyclodextrin $(\mathrm{M} \beta \mathrm{CD})$ for $30 \mathrm{~min}$. (b) Analysis of the maximum depolarization evoked by ${ }^{10} \mathrm{Panx}$ in control conditions and after the treatment with $\mathrm{M} \beta \mathrm{CD}$. (c) Time course of the changes in $\left[\mathrm{Ca}^{2+}\right]_{\mathrm{i}}$ observed in primary cultures of endothelial cells in response to ${ }^{10} \mathrm{Panx}$ application before (control) and after the treatment with $\mathrm{M} \beta \mathrm{CD}$. Values are means $\pm \mathrm{SEM} .{ }^{*} \mathrm{P}<0.05$ vs. the vehicle by one-way ANOVA plus the Newman-Keuls post hoc test. ${ }^{\dagger} P<0.05$ vs. the control by two-way ANOVA.

intact mesenteric resistance arteries (Figure 2). In resistance arteries, endothelial and smooth muscle cells are communicated through myoendothelial gap junctions $[2,38]$ and inhibition of connexin-formed channels with $\beta$-GA prevented the smooth muscle depolarization but did not affect the response in endothelial cells (Figure 2), confirming that the depolarizing signal was triggered in the endothelium and was subsequently transmitted to smooth muscle cells via myoendothelial gap junctions. Therefore, these results suggest that, in endothelial cells, Panx-1 channels may be coupled to the regulation of a depolarizing mechanism, such as $\mathrm{Na}_{\mathrm{v}}$ channels. Although voltage-dependent channels are not generally thought to be present in the endothelium, functional expression of $\mathrm{Na}_{\mathrm{v}}$ channels has been detected in endothelial cells [7, 39-41]. In this context, $\mathrm{Na}_{\mathrm{v}}$ channels have been reported to be involved in the endothelial response to shear stress [41] and to mediate the endotheliumdependent conducted vasodilation activated by depolarizing electrical stimulation of mouse cremaster arterioles [7]. Consistent with the functional association of these channels with Panx-1, the change in membrane potential triggered by the Panx-1 channel blockade was fully prevented by TTX (Figure 2). As expected, the activation of $\mathrm{Na}_{\mathrm{v}}$ channels was transient (i.e., $\sim 40 \mathrm{~ms}$ ) and only contributed to the uprising phase of the depolarization, but, in addition, this initial phase triggered a $\mathrm{Ca}^{2+}$ influx that accounted for the sustained phase of the response, as demonstrated by the removal of $\mathrm{Ca}^{2+}$ ions from the bathing solution or the treatment with mibefradil or low concentrations of $\mathrm{Ni}^{2+}(10 \mu \mathrm{M})$. In agreement with these results, application of the Panx-1 blocking peptide ${ }^{10} \mathrm{Panx}$ elicited a rapid, strong increase in $\left[\mathrm{Ca}^{2+}\right]_{\mathrm{i}}$ that paralleled the depolarization and was sensitive to TTX and $\mathrm{Ni}^{2+}$ (Figure 3). Mibefradil is a blocker of $\mathrm{Ca}_{\mathrm{v}} 3$ channels, and $\mathrm{Ni}^{2+}$, at low concentrations such as $10 \mu \mathrm{M}$, is a preferential inhibitor of the subtype $\mathrm{Ca}_{\mathrm{v}} 3.2$ of $\mathrm{Ca}_{\mathrm{v}} 3$ channels $[42,43]$. Interestingly, in the wall of resistance arteries, these channels are expressed exclusively in the endothelium $[8,27]$ and were shown to be essential for normal relaxation of the murine coronary arteries [44]. Furthermore, our results confirmed the expression of $\mathrm{Na}_{\mathrm{v}} 1.2, \mathrm{Na}_{\mathrm{v}} 1.6$, and $\mathrm{Ca}_{\mathrm{v}} 3.2$ channels in endothelial cells of rat mesenteric resistance arteries (Figure 4 and Supplementary Fig. S4). Taken together, these data indicate that the blockade of Panx-1 channels leads to the activation of a complex mechanism based on the functional coupling between TTX-sensitive $\mathrm{Na}_{\mathrm{v}}$ channels and $\mathrm{Ca}_{\mathrm{v}} 3.2$ channels, as that previously proposed to mediate the 


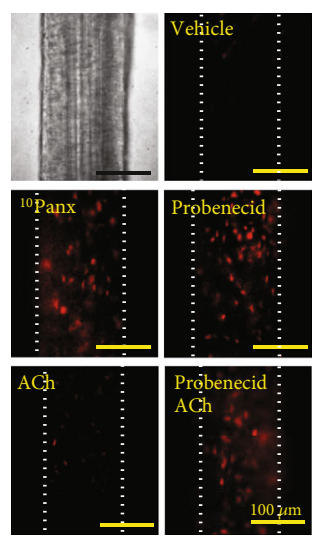

(a)
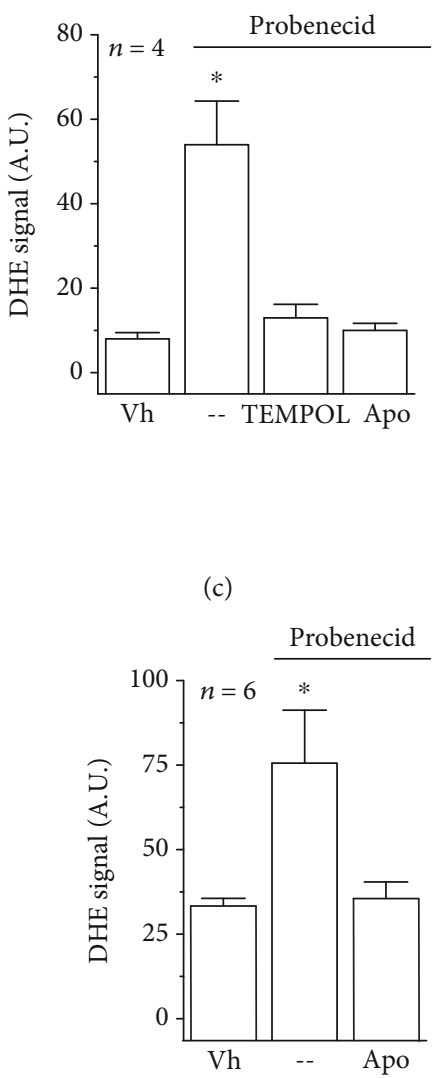

(e)

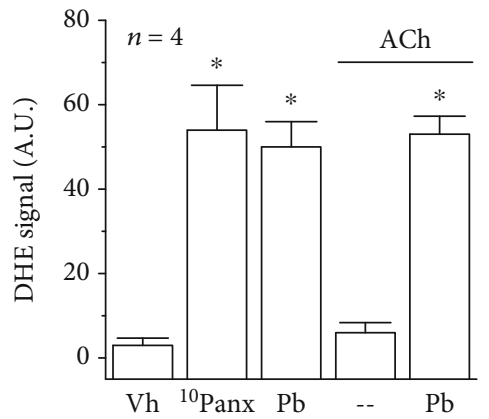

(b)
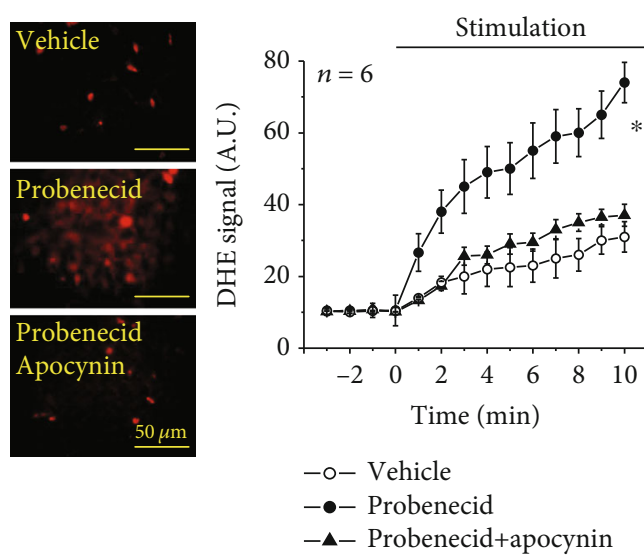

(d)

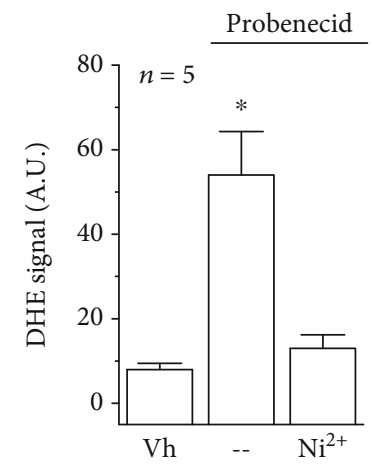

(f)

Figure 7: Blockade of Panx-1 channels leads to a NADPH oxidase-mediated increase in $\mathrm{O}_{2}{ }^{-{ }^{-}}$formation. (a) Representative images of the $\mathrm{O}_{2}{ }^{--}$generated fluorescent signal observed in intact resistance arteries after $15 \mathrm{~min}$ application of $10 \mu \mathrm{M}$ dihydroethidine (DHE) alone (control, the vehicle $(\mathrm{Vh})$ of probenecid) or with $60 \mu \mathrm{M}{ }^{10} \mathrm{Panx}, 1 \mathrm{mM}$ probenecid $(\mathrm{Pb}), 100 \mathrm{nM} \mathrm{ACh}$, or probenecid plus ACh. Dotted lines depict the outer edge of vessel walls. (b) Analysis of the $\mathrm{O}_{2}{ }^{--}$formation observed in the experiments shown in (a). (c) $\mathrm{O}_{2}{ }^{--}$production in response to probenecid in control conditions and in the presence of $10 \mu \mathrm{M}$ TEMPOL or $100 \mu \mathrm{M}$ apocynin (Apo). (d) Representative images and time course of the changes in the DHE signal observed in primary cultures of mesenteric endothelial cells in response to probenecid application in control conditions and in the presence of apocynin. The effect of the vehicle of probenecid is also shown. The horizontal bar indicates the period of stimulation. (e, f) Analysis of the maximum DHE signal attained in endothelial cell cultures in response to probenecid in control conditions and during the treatment with apocynin (e) or $\mathrm{Ni}^{2+}(\mathrm{f})$. Changes in the DHE-derived fluorescent signal are expressed in arbitrary units (A.U.). Values are means \pm SEM. ${ }^{*} P<0.05$ vs. the vehicle by one-way ANOVA plus the Newman-Keuls post hoc test.

electrically induced endothelium-dependent conducted vasodilation in mouse cremaster arterioles $[2,7]$.

The mechanism by which the blockade of Panx-1 channels triggers the activation of $\mathrm{Na}_{\mathrm{v}}$ channels requires further investigation. However, it is interesting that although Panx1 is expressed in both endothelial cells and smooth muscle cells of mesenteric resistance arteries (Figure 5), the analysis of protein association by PLA revealed that Panx-1 is found 

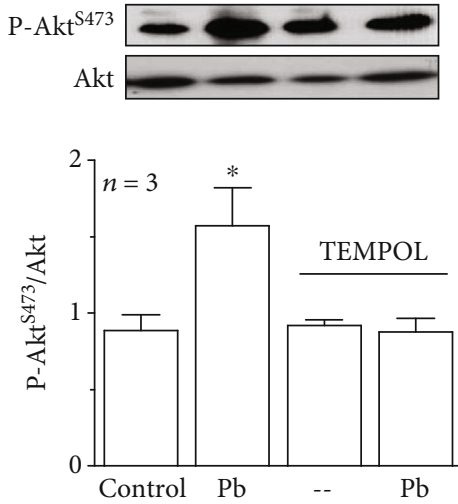

(a)

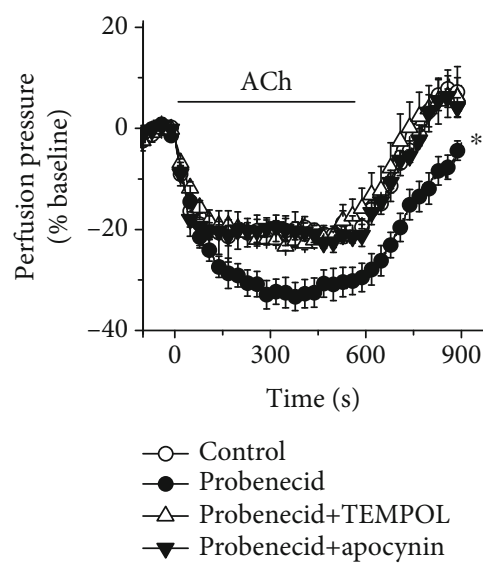

(c)
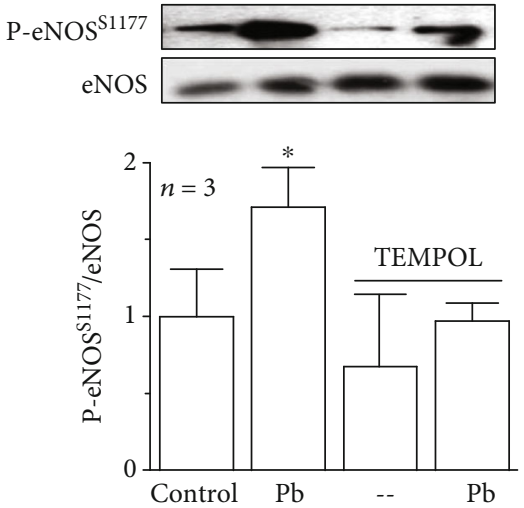

(b)

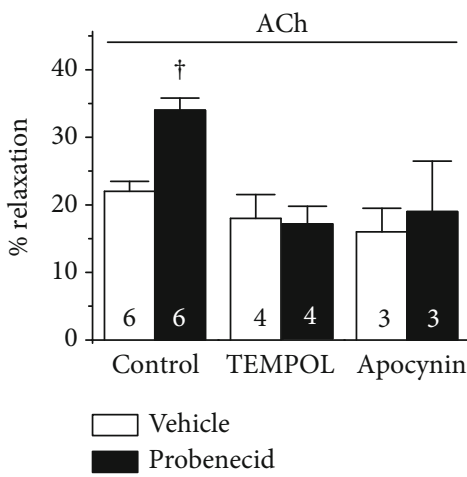

(d)

FIGURE 8: The activation of Akt signaling and eNOS phosphorylation initiated by the Panx-1 channel blockade depends on NADPH oxidasemediated $\mathrm{O}_{2}^{--}$production. ( $(\mathrm{a}, \mathrm{b})$ Representative Western blots and densitometric analysis of Akt (a), eNOS (b), Akt phosphorylation at serine $473\left(\mathrm{P}-\mathrm{Akt}^{\mathrm{S} 73},(\mathrm{a})\right)$, and eNOS phosphorylation at serine $1177\left(\mathrm{P}-\mathrm{eNOS}^{\mathrm{S1177}},(\mathrm{b})\right)$ observed in basal conditions (control) and during the treatment with $1 \mathrm{mM}$ probenecid $(\mathrm{Pb})$ in the absence or presence of $10 \mu \mathrm{M}$ TEMPOL. The effect of TEMPOL alone is also shown. In the densitometric analysis, the changes in eNOS and Akt phosphorylation are expressed as the ratio of phosphorylated protein over total protein. (c) Time course of the vasodilation induced by $100 \mathrm{nM}$ ACh in control conditions and in the presence of $1 \mathrm{mM}$ probenecid alone or in combination with $10 \mu \mathrm{M}$ TEMPOL or $100 \mu \mathrm{M}$ apocynin. Arterial mesenteric beds were constricted with $70 \mathrm{mM}$ KCl. The horizontal bar indicates the period of stimulation. (d) Maximum ACh-induced vasodilation attained during the application of probenecid or its vehicle in control conditions and in the presence of TEMPOL or apocynin. Numbers inside the bars indicate the $n$ value. Values are means \pm SEM. ${ }^{*} P<0.05$ vs. the control by one-way ANOVA plus the Newman-Keuls post hoc test. ${ }^{\dagger} P<0.05$ vs the vehicle by paired Student's t-test.

in close spatial relation with Cav-1 mainly in the endothelium (Figure 5). Cav-1 is a structural protein of caveolae [45], and the special location of Panx-1 in these signaling microdomains may provide the functional organization required to trigger the coordinated activation of $\mathrm{Na}_{\mathrm{v}}$ and $\mathrm{Ca}_{\mathrm{v}} 3.2$ channels by Panx-1 channel blockers, as these channels have been detected to be expressed in caveolae [46-48]. Interestingly, the application of Panx-1 channel blockers evokes an increase in the spatial association of Panx-1 with Cav-1 (Figure 5), which further supports the involvement of these microdomains in the response activated by the blockers. Consistent with this notion, disruption of cholesterol-rich microdomains, such as caveolae, by the treatment with $\mathrm{M} \beta \mathrm{CD}$ [49] fully prevented the ${ }^{10}$ Panx-activated depolarization and $\left[\mathrm{Ca}^{2+}\right]_{\mathrm{i}}$ increase in cultured endothelial cells (Figure 6). These results indicate that caveolae play a central role in the signaling mechanism triggered by
Panx-1 channel blockers and suggest that the analysis of protein-protein direct molecular interactions may help us to elucidate the functional connection between the Panx-1 and $\mathrm{Na}_{\mathrm{v}}$ channels, but the activation of a Panx-1-mediated receptor-like signaling cascade by probenecid or ${ }^{10} \mathrm{Panx}$ cannot be ruled out.

In endothelial cells, both depolarization of membrane potential and an increase in $\left[\mathrm{Ca}^{2+}\right]_{\mathrm{i}}$ have been shown to lead to a rise in $\mathrm{O}_{2}{ }^{--}$production by the activation of NADPH oxidase $[28-30,50,51]$. In addition, an increment in $\mathrm{O}_{2}{ }^{--}$may lead to the activation of the PI3K/Akt signaling pathway and, thereby, to the further increase in P-eNOS ${ }^{\text {S1177 }}$ [31, 52]. Three NADPH oxidase isoforms are expressed in the endothelium of rats: NOX1 oxidase, NOX2 oxidase, and NOX4 oxidase. Interestingly, of these three isoforms, only NOX1 and NOX2 generate $\mathrm{O}_{2}{ }^{--}$, since NOX4 mainly releases hydrogen peroxide $\left(\mathrm{H}_{2} \mathrm{O}_{2}\right)[31,53,54]$. Although the DHE- 
based analysis used in this study does not distinguish between $\mathrm{O}_{2}^{--}$and $\mathrm{H}_{2} \mathrm{O}_{2}$, these measurements were complemented with the direct $\mathrm{O}_{2}{ }^{--}$detection by emitted light $\left(\mathrm{ABEL}^{\circledR}\right)$ assay (Supplementary Fig. S5), which supports the participation of NOX1- or NOX2-mediated $\mathrm{O}_{2}{ }^{--}$formation in the response activated by the Panx-1 channel blockade. Consistent with this notion, the increase in the DHE signal was fully blocked by both apocynin and TEMPOL (Figure 7). In this context, it should be noted that the effect of apocynin relies on the inhibition of the p47phox subunit association with the membrane-bound heterodimer of the NADPH oxidase complex (NOX and p22phox), which is a critical process for NOX1 and NOX2 activation, but not for NOX4 function [53]. Likewise, TEMPOL is a superoxide dismutase mimetic, and thus, it buffers the increase in $\mathrm{O}_{2}{ }^{--}$with the consequent $\mathrm{H}_{2} \mathrm{O}_{2}$ production [55]. Altogether, these data indicate that the response triggered by Panx-1 blockers was associated with an increase in $\mathrm{O}_{2}{ }^{--}$formation in endothelial cells of resistance arteries (Figure 7), although the involvement of NOX1 or NOX2 in this process must be confirmed in future investigations. Furthermore, the treatment with apocynin or TEMPOL prevented the increase in $\mathrm{P}-\mathrm{Akt}^{\mathrm{S} 473}$ and $\mathrm{P}-\mathrm{eNOS}^{\mathrm{S} 1177}$ and the increment in the magnitude of the ACh-induced vasodilation (Figure 8), confirming the participation of the NADPH oxidase $/ \mathrm{O}_{2}{ }^{--}$in the Panx-1mediated control of vasomotor tone by the regulation of NO production.

It is interesting to note that Panx-1-mediated signaling may be involved in the endothelium-dependent control of peripheral vascular resistance and, consequently, arterial blood pressure. In this context, probenecid treatment in vivo has been shown to elicit a reduction in systolic blood pressure in spontaneously hypertensive rats and an increment in leg vascular conductance in humans [56, 57]. As ATP release through Panx-1 channels has been reported to contribute to the vasoconstrictor response initiated by $\alpha 1$ adrenoceptors in smooth muscle cells of resistance arteries [13], the effects of Panx-1 blockers on peripheral vascular resistance have mostly been attributed to the disruption of the purinergic-mediated component of sympathetic nervetriggered $\alpha 1$-adrenoceptor activation, although a possible direct interaction of probenecid with $\alpha$-adrenoceptors has been also proposed [56]. However, in view of our results, an increase in the NO-mediated vasodilator component through an increment in P-eNOS ${ }^{\mathrm{S1177}}$ may also be involved in the hypotensive response evoked by Panx-1 channel blockers, which highlights the potential relevance of endothelial cell Panx-1 in the control of vascular function.

\section{Conclusions}

Panx-1 channels have typically been described as a transmembrane pathway for ATP release, and accordingly, acute inhibition of the channel function is associated with the disruption of purinergic signaling [58]. However, at least in endothelial cells of resistance arteries, Panx-1 signaling seems to be more complex and is linked to eNOS phosphorylation through a NADPH oxidase $/ \mathrm{O}_{2}{ }^{-}$-mediated pathway. The results of the present work indicate that the blockade of
Panx-1 channels leads to the activation of TTX-sensitive $\mathrm{Na}_{\mathrm{v}}$ channels and the parallel recruitment of Panx-1 into caveolae, in association with Cav-1. The $\mathrm{Na}_{\mathrm{v}}$ channelmediated depolarizing current is coupled to the $\mathrm{Ca}_{\mathrm{v}} 3.2$ opening and the subsequent $\mathrm{Ca}^{2+}$ entry. Apparently, caveolae provide a signaling platform for the functional association between the Panx-1 and $\mathrm{Na}_{\mathrm{v}}$ channels. The concomitant endothelial cell depolarization and $\left[\mathrm{Ca}^{2+}\right]_{\mathrm{i}}$ increase elicit the further activation of the NADPH oxidase $/ \mathrm{O}_{2}{ }^{--}$signaling, which triggers the PI3K/Akt pathway and the subsequent increase in the ACh-induced NO-mediated vasodilation through the modulation of eNOS activity by the phosphorylation of the enzyme at serine 1177 . These findings are thus consistent with the discovery of a novel regulation mechanism of NO production and highlight the relevance of Panx-1 and $\mathrm{Na}_{\mathrm{v}}$ and $\mathrm{Ca}_{\mathrm{v}} 3$ channels in the control of endothelial cell function. This Panx-1-dependent signaling pathway is likely to play a critical role in the tonic, endothelial control of arterial blood pressure and, therefore, may contribute to the design of new therapeutic strategies for the treatment of cardiovascular-related diseases such as hypertension.

\section{Data Availability}

The data used to support the findings of this study are available from the corresponding author upon request.

\section{Conflicts of Interest}

The authors declare that there is no conflict of interest regarding the publication of this paper.

\section{Acknowledgments}

This work was supported by the Fondo Nacional de Desarrollo Científico y Tecnológico-FONDECYT (Grant \#3160348 and \#1150530). In addition, doctoral and thesis support scholarships \#21120178 and \#21120399 from Comisión Nacional de Investigatión Científica y Tecnológica (CONICYT) also contributed to support this study.

\section{Supplementary Materials}

Supplementary Figure S1. Pannexin-1 channel blockade with probenecid $(\mathrm{Pb})$ does not affect the basal perfusion pressure of mesenteric arterial beds. (a) Time course of the perfusion pressure in mesenteric arterial beds before and after probenecid application. (b) Level of perfusion pressure observed in mesenteric arteries during $10 \mathrm{~min}$ in control conditions or in the presence of probenecid. The horizontal bar indicates the period of probenecid application. Values are means \pm SEM. Supplementary Figure S2. Inhibition of the $\mathrm{KCl}$ evoked vasoconstriction by pannexin-1 channel blockade with probenecid ( $\mathrm{Pb})$. (a) and (b) Time course (a) and maximum increase in perfusion pressure (b) elicited by $\mathrm{KCl}$ (70 $\mathrm{mM}$ ) in mesenteric arteries in control conditions and in the presence of probenecid (15 $\mathrm{min})$. The horizontal bar indicates the period of $\mathrm{KCl}$ stimulation. Values are means \pm SEM. ${ }^{*}, P<0.05$ vs Control by paired Student's t test. Supplementary Figure S3. The vasodilation induced by 
acetylcholine (ACh) depends exclusively on NO production in $\mathrm{KCl}$-contracted resistance arteries. Time course of changes in perfusion pressure elicited by $1 \mathrm{~min}$ stimulation with 100 $\mathrm{nM}$ ACh in control conditions and after blocking NO production with $100 \mu \mathrm{M} \mathrm{N}^{G}$-nitro-L-arginine (L-NA) in arterial mesenteric vessels contracted with $70 \mathrm{mM} \mathrm{KCl}$. The horizontal bar indicates the period of ACh stimulation. Values are means \pm SEM. Supplementary Figure S4. Plasma membrane expression of $\mathrm{Na}_{\mathrm{v}} 1.2, \mathrm{Na}_{\mathrm{v}} 1.6$ and $\mathrm{Ca}_{\mathrm{v}} 3.2$ channels in mesenteric resistance arteries. The presence of these channels in the plasma membrane was analyzed by biotinylation of cell surface proteins. Mesenteric arteries were perfused with $1 \mathrm{mM}$ sulfosuccinimidyl-2-[biotinamido] ethyl-1,3-dithiopropionate for $40 \mathrm{~min}$ at $0.5 \mathrm{~mL} / \mathrm{min}$ to label membrane proteins of the luminal surface of the vessels. Then, tissues were homogenized and proteins were precipitated with ice-cold acetone. The pellet was suspended in Tris-buffer, the biotinylated proteins were captured with streptavidin-agarose beads and separated by SDS-PAGE to be detected with specific antibodies. A representative Western blot of three independent experiments is shown. The presence of eNOS, $\mathrm{Na}^{+}-\mathrm{Ca}^{2+}$ exchanger and the channels $\mathrm{Na}_{\mathrm{v}} 1.2, \mathrm{Na}_{\mathrm{v}} 1.6, \mathrm{Ca}_{\mathrm{v}} 3.2$ and $\mathrm{Ca}_{\mathrm{v}} 1.2$ was evaluated in the total tissue homogenized $(\mathbf{H})$ and in the fraction of biotinylated-plasma membrane proteins $(\mathbf{M})$. In addition to $\mathrm{Na}_{\mathrm{v}} 1.2, \mathrm{Na}_{\mathrm{v}} 1.6$ and $\mathrm{Ca}_{\mathrm{v}} 3.2$ channels, eNOS and $\mathrm{Ca}_{\mathrm{v}} 1.2$ were also analyzed as negative control to confirm that the biotin treatment did not label intracellular proteins of endothelial cells or plasma membrane proteins of smooth muscle cells. In addition, $\mathrm{Na}^{+}-\mathrm{Ca}^{2+}$ exchanger (NCX) was used as a positive control for the detection of plasma membrane proteins of endothelial cells. Supplementary Figure S5. Superoxide anion $\left(\mathrm{O}_{2}{ }^{-}\right)$production activated by probenecid $(\mathrm{Pb})$. $\mathrm{O}_{2}{ }^{--}$levels were measured in isolated mesenteric arterial beds of rats using the analysis by emitted light $\left(\mathrm{ABEL}^{\circledR}\right)$ assay, which is based on the intense luminescence emitted upon reaction of $\mathrm{O}_{2}^{-{ }^{-}}$radicals with the prosthetic group of Pholasin, the photoprotein responsible for luminescence in the bivalve Pholas dactylus. After treating mesenteric vessels with the pannexin-1 channel blocker, probenecid, or its vehicle, $20 \mu \mathrm{L}$ of perfusate samples were mixed with $100 \mu \mathrm{L}$ of adjuvant $-\mathrm{K}^{\mathrm{TM}}$ solution and, following $1 \mathrm{~min}$ of equilibration, the reaction was initiated by the injection of $250 \mu \mathrm{L}$ of Pholasin solution $(10 \mu \mathrm{g} / \mathrm{mL})$. The resulting luminescence was immediately measured on a Turner TD20e luminometer (Promega). Adjuvant- $\mathrm{K}^{\mathrm{TM}}$ and pholasin solutions were prepared using the reconstitution buffer (Hank's balanced salt solution with $20 \mathrm{mM}$ HEPES, pH 7.4) as indicated by the manufacturer (Knight Scientific Ltd.). Changes in $\mathrm{O}_{2}{ }^{-}$formation are expressed in arbitrary units (AU). Numbers inside the bars indicate the $\mathrm{n}$ value. All measurements were made in duplicate. Values are means \pm SEM. ${ }^{*}, P<0.05$ vs Vehicle by unpaired Student's t test. Supplementary Figure S6. The inhibition of the $\mathrm{KCl}$-elicited vasoconstriction evoked by pannexin-1 channel blockade with probenecid $(\mathrm{Pb})$ depends on a NADPH oxidase-initiated superoxide anion signaling. (a) and (b) Effect of probenecid on the time course (Left) and maximum increase in perfusion pressure (Right) evoked by $\mathrm{KCl}(70 \mathrm{mM})$ in mesenteric arteries treated with TEMPOL (a), a superoxide scavenger, or apocynin (b), a
NADPH oxidase inhibitor. Note that the reduction in the KCl-induced vasoconstriction observed after pannexin-1 channel blockade with probenecid (Supplementary Fig. S2) is fully prevented by TEMPOL. (a) and apocynin (b). Horizontal bars indicate the period of $\mathrm{KCl}$ stimulation (Left) or the treatment applied (Right). Values are means \pm SEM. (Supplementary Materials)

\section{References}

[1] M. J. Durand and D. D. Gutterman, "Diversity in mechanisms of endothelium-dependent vasodilation in health and disease," Microcirculation, vol. 20, no. 3, pp. 239-247, 2013.

[2] X. F. Figueroa and B. R. Duling, "Gap junctions in the control of vascular function," Antioxidants \& Redox Signaling, vol. 11, no. 2, pp. 251-266, 2009.

[3] R. Busse, G. Edwards, M. Félétou, I. Fleming, P. M. Vanhoutte, and A. H. Weston, "EDHF: bringing the concepts together," Trends in Pharmacological Sciences, vol. 23, no. 8, pp. 374380, 2002.

[4] I. Eichler, J. Wibawa, I. Grgic et al., "Selective blockade of endothelial $\mathrm{Ca} 2+$-activated small- and intermediateconductance $\mathrm{K}+$-channels suppresses EDHF-mediated vasodilation," British Journal of Pharmacology, vol. 138, no. 4, pp. 594-601, 2003.

[5] M. Félétou and P. M. Vanhoutte, "Endothelium-dependent hyperpolarization : no longer an F-word !," Journal of Cardiovascular Pharmacology, vol. 61, no. 2, pp. 91-92, 2013.

[6] X. F. Figueroa, M. A. Lillo, P. S. Gaete, M. A. Riquelme, and J. C. Sáez, "Diffusion of nitric oxide across cell membranes of the vascular wall requires specific connexin-based channels," Neuropharmacology, vol. 75, pp. 471-478, 2013.

[7] X. F. Figueroa, C.-C. Chen, K. P. Campbell et al., "Are voltagedependent ion channels involved in the endothelial cell control of vasomotor tone?," American Journal of Physiology-Heart and Circulatory Physiology, vol. 293, pp. H1371-H1383, 2007.

[8] I. Proost, I. Brouns, I. Pintelon, J.-P. Timmermans, and D. Adriaensen, "Pulmonary expression of voltage-gated calcium channels: special reference to sensory airway receptors," Histochemistry and Cell Biology, vol. 128, no. 4, pp. 301-316, 2007.

[9] W. H. Evans and P. E. M. Martin, "Gap junctions: structure and function," Molecular Membrane Biology, vol. 19, pp. 121-136, 2009.

[10] J. C. Sáez, K. A. Schalper, M. A. Retamal, J. A. Orellana, K. F. Shoji, and M. V. L. Bennett, "Cell membrane permeabilization via connexin hemichannels in living and dying cells," Experimental Cell Research, vol. 316, no. 15, pp. 2377-2389, 2010.

[11] D. Begandt, M. E. Good, A. S. Keller et al., "Pannexin channel and connexin hemichannel expression in vascular function and inflammation," BMC Cell Biology, vol. 18, no. S1, pp. 216, 2017.

[12] B. E. Isakson, S. I. Ramos, and B. R. Duling, "Ca2+ and inositol 1, 4, 5-trisphosphate-mediated signaling across the myoendothelial junction," Circulation Research, vol. 100, no. 2, pp. 246-254, 2007.

[13] M. Billaud, A. W. Lohman, A. C. Straub et al., "Pannexin1 regulates $\alpha 1$-adrenergic receptor- mediated vasoconstriction," Circulation Research, vol. 109, no. 1, pp. 80-85, 2011.

[14] F. Molica, X. F. Figueroa, B. R. Kwak, B. E. Isakson, and J. M. Gibbins, "Connexins and pannexins in vascular function and 
disease," International Journal of Molecular Sciences, vol. 19, no. 6, 2018.

[15] M. Koval, B. E. Isakson, and R. G. Gourdie, "Connexins, pannexins and innexins: protein cousins with overlapping functions," FEBS Letters, vol. 588, no. 8, p. 1185, 2014.

[16] A. W. Lohman, M. Billaud, A. C. Straub et al., "Expression of pannexin isoforms in the systemic murine arterial network," Journal of Vascular Research, vol. 49, no. 5, pp. 405-416, 2012.

[17] D. Gaynullina, V. I. Shestopalov, Y. Panchin, and O. S. Tarasova, "Pannexin 1 facilitates arterial relaxation via an endothelium-derived hyperpolarization mechanism," FEBS Letters, vol. 589, no. 10, pp. 1164-1170, 2015.

[18] M. A. Lillo, P. S. Gaete, M. Puebla et al., "Critical contribution of $\mathrm{Na}+-\mathrm{Ca} 2+$ exchanger to the $\mathrm{Ca} 2+$-mediated vasodilation activated in endothelial cells of resistance arteries," The FASEB Journal, vol. 32, no. 4, pp. 2137-2147, 2018.

[19] P. S. Gaete, M. A. Lillo, N. M. Ardiles, F. R. Pérez, and X. F. Figueroa, " $\mathrm{Ca}^{2+}$-activated $\mathrm{K}^{+}$channels of small and intermediate conductance control eNOS activation through $\mathrm{NAD}(\mathrm{P}) \mathrm{H}$ oxidase," Free Radical Biology \& Medicine, vol. 52, no. 5, pp. 860-870, 2012.

[20] R. A. Ashley, S. H. Dubuque, B. Dvorak, S. S. Woodward, S. K. Williams, and P. J. Kling, "Erythropoietin stimulates vasculogenesis in neonatal rat mesenteric microvascular endothelial cells," Pediatric Research, vol. 51, no. 4, pp. 472-478, 2002.

[21] L. Benov, L. Sztejnberg, and I. Fridovich, "Critical evaluation of the use of hydroethidine as a measure of superoxide anion radical," Free Radical Biology \& Medicine, vol. 25, no. 7, pp. 826831, 1998.

[22] T. Müller, E. V. Davies, and A. K. Campbell, "Pholasin chemiluminescence detects mostly superoxide anion released from activated human neutrophils," Journal of Bioluminescence and Chemiluminescence, vol. 3, no. 3, pp. 105-113, 1989.

[23] L. Selloum, S. Reichl, M. Müller, L. Sebihi, and J. Arnhold, "Effects of flavonols on the generation of superoxide anion radicals by xanthine oxidase and stimulated neutrophils," Archives of Biochemistry and Biophysics, vol. 395, no. 1, pp. 49-56, 2001.

[24] A. M. Zeiher, S. Dimmeler, I. Fleming, B. Fisslthaler, C. Hermann, and R. Busse, "Activation of nitric oxide synthase in endothelial cells by Akt-dependent phosphorylation," Nature, vol. 399, no. 6736, pp. 601-605, 1999.

[25] D. Fulton, J.-P. Gratton, T. J. Mccabe et al., "Regulation of endothelium-derived nitric oxide production by the protein kinase Akt," Nature, vol. 399, no. 6736, pp. 597-601, 1999.

[26] M. B. Harris, H. Ju, V. J. Venema et al., "Reciprocal phosphorylation and regulation of endothelial nitric-oxide synthase in response to bradykinin stimulation," The Journal of Biological Chemistry, vol. 276, no. 19, pp. 16587-16591, 2001.

[27] A. M. Blanks, Z.-H. Zhao, A. Shmygol, G. Bru-Mercier, S. Astle, and S. Thornton, "Characterization of the molecular and electrophysiological properties of the T-type calcium channel in human myometrium," The Journal of Physiology, vol. 581, no. 3, pp. 915-926, 2007.

[28] H. Y. Sohn, M. Keller, T. Gloe, H. Morawietz, U. Rueckschloss, and U. Pohl, "The small G-protein Rac mediates depolarization-induced superoxide formation in human endothelial cells," The Journal of Biological Chemistry, vol. 275, no. 25, pp. 18745-18750, 2000.

[29] P. Minuz, A. Meneguzzi, L. Fumagalli et al., "Calcium-dependent Src phosphorylation and reactive oxygen species genera- tion are implicated in the activation of human platelet induced by thromboxane A2 analogs," Frontiers in Pharmacology, vol. 9, p. 1081, 2018.

[30] S. Lange, J. Heger, G. Euler, M. Wartenberg, H. M. Piper, and H. Sauer, "Platelet-derived growth factor BB stimulates vasculogenesis of embryonic stem cell-derived endothelial cells by calcium-mediated generation of reactive oxygen species," Cardiovascular Research, vol. 81, pp. 159-168, 2008.

[31] R. S. Frey, M. Ushio-Fukai, and A. B. Malik, "NADPH oxidasedependent signaling in endothelial cells: role in physiology and pathophysiology," Antioxidants \& Redox Signaling, vol. 11, pp. 791-810, 2009.

[32] P. S. Gaete, M. A. Lillo, M. Puebla, I. Poblete, and X. F. Figueroa, "CGRP signalling inhibits NO production through pannexin-1 channel activation in endothelial cells," Scientific Reports, vol. 9, no. 1, p. 7932, 2019.

[33] I. Fleming and R. Busse, "Molecular mechanisms involved in the regulation of the endothelial nitric oxide synthase," American Journal of Physiology. Regulatory, Integrative and Comparative Physiology, vol. 284, no. 1, pp. R1-R12, 2003.

[34] P. F. Mount, B. E. Kemp, and D. A. Power, "Regulation of endothelial and myocardial NO synthesis by multi-site eNOS phosphorylation," Journal of Molecular and Cellular Cardiology, vol. 42, no. 2, pp. 271-279, 2007.

[35] Y. C. Boo and H. Jo, "Flow-dependent regulation of endothelial nitric oxide synthase: role of protein kinases," American Journal of Physiology-Cell Physiology, vol. 285, pp. C499C508, 2003.

[36] W. Ma, V. Compan, W. Zheng et al., "Pannexin 1 forms an anion-selective channel," Pflugers Arch. Eur. J. Physiol., vol. 463, no. 4, pp. 585-592, 2012.

[37] P. Fransen and S. U. Sys, "K+ and Cl- contribute to resting membrane conductance of cultured porcine endocardial endothelial cells," American Journal of Physiology-Heart and Circulatory Physiology, vol. 272, pp. H1770-H1779, 1997.

[38] S. L. Sandow, R. Looft-Wilson, B. Doran, T. H. Grayson, S. S. Segal, and C. E. Hill, "Expression of homocellular and heterocellular gap junctions in hamster arterioles and feed arteries," Cardiovascular Research, vol. 60, no. 3, pp. 643-653, 2003.

[39] D. V. Gordienko and H. Tsukahara, “Tetrodotoxin-blockable depolarization-activated $\mathrm{Na}+$ currents in a cultured endothelial cell line derived from rat interlobar arter and human umbilical vein," Pflügers Archiv European Journal of Physiology, vol. 428, no. 1, pp. 91-93, 1994.

[40] K. B. Walsh, M. B. Wolf, and J. Fan, "Voltage-gated sodium channels in cardiac microvascular endothelial cells," American Journal of Physiology-Heart and Circulatory Physiology, vol. 274, no. 2, pp. H506-H512, 1998.

[41] O. Traub, T. Ishida, M. Ishida, J. C. Tupper, and B. C. Berk, "Shear stress-mediated extracellular signal-regulated kinase activation is regulated by sodium in endothelial cells," The Journal of Biological Chemistry, vol. 274, no. 29, pp. 20144 20150, 1999.

[42] J.-H. Lee, J. C. Gomora, L. L. Cribbs, and E. Perez-reyes, "Nickel block of three cloned T-type calcium channels: low concentrations selectively block_ $\alpha \_1 \mathrm{H}$," Biophysical Journal, vol. 77, no. 6, pp. 3034-3042, 1999.

[43] A. M. R. Yunker, "Modulation and pharmacology of low voltage-activated ("T-type") calcium channels," Journal of Bioenergetics and Biomembranes, vol. 35, no. 6, pp. 577-598, 2003. 
[44] C.-C. Chen, K. G. Lamping, D. W. Nuno et al., "Abnormal coronary function in mice deficient in $1 \mathrm{H}$ T-type Ca2+ channels," Science, vol. 302, pp. 1416-1418, 2003.

[45] G. Sowa, "Caveolae, caveolins, cavins, and endothelial cell function: new insights," Frontiers in Physiology, vol. 2, pp. 113, 2012.

[46] T. L. Yarbrough, T. Lu, H. C. Lee, and E. F. Shibata, "Localization of cardiac sodium channels in caveolin-rich membrane domains: regulation of sodium current amplitude," Circulation Research, vol. 90, no. 4, pp. 443-449, 2002.

[47] E. E. Daniel, W. J. Cho, A. El-Yazbi, and W. J. Cho, "Caveolae and calcium handling, a review and a hypothesis," Journal of Cellular and Molecular Medicine, vol. 10, no. 2, pp. 529-544, 2006.

[48] M. Isshiki and R. G. W. Anderson, "Function of caveolae in Ca2+ entry and Ca2+-dependent signal transduction," Traffic, vol. 4, no. 11, pp. 717-723, 2003.

[49] E. P. C. Kilsdonk, P. G. Yancey, G. W. Stoudt et al., "Cellular cholesterol efflux mediated by cyclodextrins," The Journal of Biological Chemistry, vol. 270, no. 29, pp. 17250-17256, 1995.

[50] I. Matsuzaki, S. Chatterjee, K. Debolt, Y. Manevich, Q. Zhang, and A. B. Fisher, "Membrane depolarization and NADPH oxidase activation in aortic endothelium during ischemia reflect altered mechanotransduction," American Journal of Physiology. Heart and Circulatory Physiology, vol. 288, no. 1, pp. H336-H343, 2005.

[51] P. Chaudhuri, M. A. Rosenbaum, L. Birnbaumer, and L. M. Graham, "Integration of TRPC6 and NADPH oxidase activation in lysophosphatidylcholine-induced TRPC5 externalization," American Journal of Physiology. Cell Physiology, vol. 313, no. 5, pp. C541-C555, 2017.

[52] F. Zgheel, M. Alhosin, S. Rashid, M. Burban, C. Auger, and V. B. Schini-Kerth, "Redox-sensitive induction of Src/PI3kinase/Akt and MAPKs pathways activate eNOS in response to EPA:DHA 6:1," PLoS One, vol. 9, no. 8, article e105102, 2014.

[53] G. R. Drummond, S. Selemidis, K. K. Griendling, and C. G. Sobey, "Combating oxidative stress in vascular disease: NADPH oxidases as therapeutic targets," Nature Reviews. Drug Discovery, vol. 10, no. 6, pp. 453-471, 2011.

[54] B. Lassègue and K. K. Griendling, "NADPH oxidases: functions and pathologies in the vasculature," Arteriosclerosis, Thrombosis, and Vascular Biology, vol. 30, no. 4, pp. 653661, 2010.

[55] Y. Chen, A. Pearlman, Z. Luo, and C. S. Wilcox, "Hydrogen peroxide mediates a transient vasorelaxation with tempol during oxidative stress," American Journal of Physiology-Heart and Circulatory Physiology, vol. 293, pp. H2085-H2092, 2007.

[56] J. B. Park and S. J. Kim, "Anti-hypertensive effects of probenecid_via_inhibition of the $\alpha$-adrenergic receptor," Pharmacological Reports, vol. 63, no. 5, pp. 1145-1150, 2011.

[57] M. Nyberg, P. Piil, O. T. Kiehn et al., "Probenecid inhibits $\alpha$ adrenergic receptor-mediated vasoconstriction in the human leg vasculature," Hypertension, vol. 71, no. 1, pp. 151-159, 2018.

[58] A. W. Lohman, M. Billaud, and B. E. Isakson, "Mechanisms of ATP release and signalling in the blood vessel wall," Cardiovascular Research, vol. 95, no. 3, pp. 269-280, 2012. 